\title{
The collembolan fauna of the East European tundra
}

\section{Фауна комлембол (Collembola) восточно-европейских тундр}

\author{
A.B. Babenko, ${ }^{1,2}$ M.B. Potapov ${ }^{3}$, A.A. Taskaeva ${ }^{4}$ \\ А.Б. Бабенко ${ }^{1,2}$, М.Б. Потапов ${ }^{3}$, А.А. Таскаева ${ }^{4}$
}

\footnotetext{
${ }^{1}$ The Severtsov Institute of Ecology and Evolution, Russian Academy of Sciences, Leninski pr. 33, Moscow 119071, Russia. E-mail: 1sdc@mail.ru

${ }^{1}$ Институт проблем экологии и эволюции РАН им. А.Н. Северцова,Ленинский пр., 33, Москва 119071.

${ }^{2}$ The Lomonosov Northern (Arctic) Federal University, Severnaya Dvina emb. 17, Arkhangelsk, 163002, Russia.

${ }^{2}$ Северный (Арктический) федеральный университет им. М.В. Ломоносова, наб. Северной Двины, 17, Архангельск 163002.

${ }^{3}$ Moscow Pedagogical State University, Institute of Biology and Chemistry, Kibalchicha str. 6, Bld. 5, Moscow 129164, Russia. E-mail: mpnk-abroad@yandex.ru

${ }^{3}$ Московский педагогический университет, Институт биологии и химии, ул. Кибальчича, 6, стр.3, Москва 129164.

${ }^{4}$ Institute of Biology, Komi Science Center, Ural Division of Russian Academy of Sciences, Kommunisticheskaya str. 28, Syktyvkar 167982, Russia. E-mail: taskaeva@ib.komisc.ru

${ }^{4}$ Институт биологии Коми НЦ УрО РАН, ул. Коммунистическая, 28, Сыктывкар 167982.
}

KEY WORDS: springtails, annotated list, new species, taxonomic remarks, distribution, northeastern Europe.

КЛЮЧЕВЫЕ СЛОВА: ногохвостки, аннотированный список, новые виды, таксономические замечания, распространение, Северо-Восточная Европа.

ABSTRACT. The present review of the collembolan fauna of the East European tundra is based on existing published data and new material collected recently in the region by the authors. Four new species, i.e. Hymenaphorura inopinata sp.n., Gisinea subtilia sp.n., Pachyotoma miserabilis sp.n., and Desoria breviseta sp.n., are described. The generic position and morphological peculiarities of a number of problematic forms are discussed. General geographic ranges of all species concerned as well as characteristic of their distribution within the study region are given. The specificity of the fauna of this European region is highlighted as being due to high proportions of eastern elements, i.e. forms with East Palaearctic or East Palaearctic + Nearctic distributional patterns.

РЕЗЮМЕ. Представлен обзор фауны ногохвосток восточно-европейских тундр, основанный на имеющихся литературных данных и собственных материалов, собранных за последнее время. Описано 4 новых вида: Hymenaphorura inopinata sp.n., Gisinea subtilia sp.n., Pachyotoma miserabilis sp.n. и Desoria breviseta sp.n. Для всех отмеченных видов приведены сведения об общем ареале и распространении в восточно-европейских тундрах, обсуждены положение и морфологические особенности ряда проблемных видов. Отмечена специфичность фауны данного европейского региона из-за высокой представленности восточных элементов, т.е. восточно-палеарктических или восточно-палеарктическо-неарктических форм.

The present review is mainly devoted to the springtail fauna of Malozemel'skaya and Bolshezemel'skaya tundras, i.e. territory bounded by the Kanin Peninsula on the west and the Kara River basin on the east. Several islands of the Barents Sea (Kolguev, Dolgii and Vaigach) are also included. Unfortunately we have to exclude the Karskay Tundra east of Kara River because modern material from this region is absent ${ }^{1}$.

The earliest data on springtails from the territory under consideration was collected by the 1903 Finnish zoological expedition headed by B.R. Poppius. During three months the expedition explored both the southern parts of Kanin Peninsula along its western coast and its northern extremity (basin of rivers Krinka, Madaga and Rybnaya). Springtail material of the expedition was studied by Finnish entomologist W. Linnaniemi (Axelson), who recorded [1909] not less than 32 species and varieties from the treeless parts of the peninsula. Unfortunately, not all of them are possible to interpret in modern terms.

During the last century, there were almost no further special studies that dealt with Collembola in the region. Only three brief papers were published [Kozlovskaya, 1955, 1957, Bombusova, Kuznetsova, 1981] which focused on the southern part of the Bolshezemel'skaya Tundra. The first modern information appeared only in the mid- $90^{\text {th }}$ after a Russian-Swedish joint expedition had visited three localities along the Barents Sea shore. Despite a severe time shortage (two days per point) 88 species were found. Those data was used in reviews of two genera in the northern Palaearctic, i.e. Anurida

Based on the collection of the 1909 Ural expedition headed by O.O. Backlund, Linnaniemi [1919] recorded 10 species and varieties for the Karskaya tundra; among them, only 6 are safely recognizable. 
[Babenko, 1997] and Folsomia [Potapov, Babenko, 2000], as well as in a catalogue of the Arctic springtails [Babenko, Fjellberg, 2006].

Several local faunistic lists of springtails have since been compiled concerning the coastal habitats of the Malozemel'skaya Tundra [Taskaeva, Nakul, 2010, 2011], the southern regions of Bolshezemel'skaya Tundra [Kolesnikova et al., 2008; Goryachkin et al., 2011; Zubrii et al., 2011] and the Dolgii Island [Babenko, 2012] have been published.

In the summer of 2015, a vast material was collected in three coastal regions of the Bolshezemel'skaya Tundra by an expedition of the Severtsov Institute of Ecology and Evolution, Russian Academy of Sciences in the framework of a joint project of the United Nations Development Programme (UNDP) and the Ministry of Natural Resources and Environment of the Russian Federation, "Challenges of diversity conservation in politics and developmental programmes of the energy sector of the Russian economy" (2014-2016). This material is a main source of the annotated list presented below, in which some unpublished, new data from the Vaigach and Kolguev islands, the Chernaya River basin, the lower reaches of Velt River, the Kolokolkovskaya Guba, and the vicinity of Vorkuta were also included. All these localities are listed in Table 1 and mapped on Fig.1.

Table 1. Localities of collembolan collections within the East European tundra Таблица 1. Районы сборов ногохвосток в пределах восточно-европейских тундр

\begin{tabular}{|c|c|c|c|}
\hline \multirow{2}{*}{ locality } & \multicolumn{2}{|c|}{ Coordinates } & \multirow{2}{*}{ Source } \\
\hline & $\mathrm{N}^{\circ}$ & $E^{\circ}$ & \\
\hline 1 Kanin Peninsula, settlement Ness & 66.60 & 44.68 & Linnaniemi, 1909 \\
\hline 2 Kanin Peninsula, lower reaches of Chizha River & 67.06 & 44.32 & Linnaniemi, 1909 \\
\hline 3 Kanin Peninsula, Konushin Nos Point & 67.20 & 43.78 & Linnaniemi, 1909 \\
\hline 4 Kanin Peninsula, lower reaches of Chesha River & 67.34 & 44.91 & Linnaniemi, 1909 \\
\hline 5 Kanin peninsula, lower reaches of Bugryanitsa River & 68.23 & 44.23 & Linnaniemi, 1909 \\
\hline 6 Kanin Peninsula, Tarkhanov Point & 68.50 & 43.64 & Linnaniemi, 1909 \\
\hline 7 Kanin peninsula, lower reaches of Krynka River & 68.54 & 44.29 & Linnaniemi, 1909 \\
\hline 8 Kanin peninsula, lower reaches of Madakha River & 68.55 & 44.77 & Linnaniemi, 1909 \\
\hline 9 Kanin peninsula, lower reaches of Rybnaya River & 68.10 & 46.55 & Linnaniemi, 1909 \\
\hline 10 Kanin peninsula, middle reaches of Rybnaya River & 68.13 & 46.09 & unpublished data, A. Babenko leg. \\
\hline 11 Malozemel'skaya Tundra, lower reaches of Velt River & 68.08 & 50.05 & $\begin{array}{l}\text { Taskaeva, Nakul, 2011; unpublished data, A. } \\
\text { Taskaeva, G. Nakul leg. }\end{array}$ \\
\hline 12 Kolguev Island, Goltsovoe Lake & 69.20 & 49.18 & unpublished data, A. Babenko leg. \\
\hline 13 Kolguev Island, middle reaches of Peschanka River & 69.15 & 49.28 & unpublished data, S. Rozenfeld leg. \\
\hline 14 Kolokolkovskaya Guba, Chayachii Island & 68.54 & 52.33 & $\begin{array}{l}\text { Taskaeva, Nakul, 2010; unpublished data, A. } \\
\text { Taskaeva, G. Nakul leg. }\end{array}$ \\
\hline 15 Kolokolkovskyi Nos & 68.59 & 52.29 & $\begin{array}{l}\text { Taskaeva, Nakul, 2010; unpublished data, A. } \\
\text { Taskaeva, G. Nakul leg. }\end{array}$ \\
\hline 16 Pechorskaya Guba, Kuznetskoe Lake & 68.84 & 53.48 & unpublished data, A. Babenko leg. \\
\hline 17 Bolvanskaya Guba & 68.22 & 54.78 & unpublished data, O. Makarova, M. Bizin leg. \\
\hline 18 Chernaya River basin & 68.26 & 56.34 & unpublished data, T. Konakova, G. Nakul leg. \\
\hline 19 Pakhancheskaya Guba & 68.48 & 57.22 & unpublished data, O. Makarova, M. Bizin leg. \\
\hline 20 Dolgii Island, Pechora Sea & 69.20 & 59.22 & Babenko, 2012 \\
\hline 21 Khaipudyrskaya Guba & 68.28 & 59.95 & unpublished data, O. Makarova, M. Bizin leg. \\
\hline 22 Vaigach Isl., upper reaches of Talata-Karskaya River & 70.22 & 59.26 & unpublished data, N. Zubrii, B. Filippov leg. \\
\hline 23 Vaigach Isl., vicinity of Varnek & 69.72 & 60.06 & unpublished data, A. Babenko leg. \\
\hline 24 Belyi Nos, Yugorskii Peninsula & 69.61 & 60.22 & unpublished data, A. Babenko leg. \\
\hline 25 Pymvashor & 67.19 & 60.87 & $\begin{array}{l}\text { Zubrii et al., 2011; unpublished data, N. } \\
\text { Zubrii, B. Filippov leg. }\end{array}$ \\
\hline 26 Lakes Padymeiskie & 67.85 & 63.37 & Taskaeva et al., 2015 \\
\hline 27 Vicinity of Vorkuta & 67.50 & 64.06 & $\begin{array}{l}\text { Kolesnikova et al., 2008; Goryachkin et al., } \\
\text { 2011; unpublished data, A. Taskaeva leg. }\end{array}$ \\
\hline 28 Vicinity of Sivaya Maska & 66.67 & 62.57 & Bombusova, Kuznetsova, 1981 \\
\hline
\end{tabular}

ABBREVIATIONS: $A b d .1-6$ - abdominal segments I-VI; accp - accessory $p$-row $s$-seta; Ant.1-4 antennal segments 1-4; al - anterolateral $s$-seta; as anterosubmedial $s$-seta; $A O$ - antennal organ on antennal segment 3; $A S$ - anal spines; bms - basal micro $s$ seta on antennal segments; $G, H$ - ocelli $\mathrm{G}$ and $\mathrm{H}$; Leg $1,2,3$ - first, second and third pairs of legs; $m s$ - micro $s$-seta(e) (= microsensillum(a) auct.); $s$ - macro $s$-seta or $s$-setae (= macrosensillum(a) or sensillum(a) auct.); pso — pseudocellus(-i), psx — parapseudocellus(-i); $P A O$ - postantennal organ; Th.1-3 - thoracic segments 1-3; Ti.1,2,3 - tibiotarsus of first, second and third pairs of legs; $U_{3}$ - inner edge of unguis of third pairs of legs; $V T$ - ventral tube. 


\section{List of species}

\section{Poduridae}

Podura aquatica Linnaeus, 1758

DISTRIBUTION in the East European tundra. Probably all over the region in water-logged habitats, but only a few trustworthy records $(10,11,20,21,25)$.

GENERAL DISTRIBUTION. Holarctic, although recent barcoding surveys in the Canadian Arctic [Hogg, Hebert 2004; Porco et al., 2014] revealed a probable presence of several cryptic lineages in $P$. aquatica auct.

\section{Tullbergiidae}

Mesaphorura jirii Rusek, 1982

DISTRIBUTION in the East European tundra. Common and can be abundant, usually in rich herbaceous sites all over the region $(12,13,17,19,20,22,27)$.

GENERAL DISTRIBUTION. Amphi-Atlantic species (Europe including Svalbard and Iceland, Greenland).

Mesaphorura krausbaueri Börner, 1901

DISTRIBUTION in the East European tundra. Most older records (for instance, 28) can belong to other congeners, although the species does occur in the region and clearly prefers its southern part (27) or forest islands within true tundra landscapes (25).

GENERAL DISTRIBUTION. Cosmopolitan [?].

Mesaphorura macrochaeta Rusek, 1976

DISTRIBUTION in the East European tundra. The most common and abundant species of the genus in the region (11,
$13,16,17,18,19,20,21,23,24,25,26)$. GENERAL DISTRIBUTION. Cosmopolitan [?].

Mesaphorura tenuisensillata Rusek, 1974

DISTRIBUTION in the East European tundra. Common, but less frequent than the previous species $(10,12,13,17,22)$. GENERAL DISTRIBUTION. Trans-Palaearctic, including Iceland and Svalbard, Greenland.

Stenaphorura quadrispina Börner, 1901

DISTRIBUTION in the East European tundra. A species rare in the region, found in its southern parts $(10,25,28)$.

GENERAL DISTRIBUTION. Palaearctic with probable records from Australia and South America [Mari Mutt, Bellinger, 1990; Greenslade, 1994].

Tullbergia simplex Gisin, 1958

TAXONOMIC REMARKS. There is no common opinion about the generic position of this species, as well as of two other related arctic forms, arctica Wahlgren, 1900 and bella Fjellberg, 1984. All of them were originally described in Tullbergia, although $T$. antarctica Lubbock, 1876, the type species of the genus, strongly differs from this distinct Arctic group which, according to the modern criteria, is obviously to be placed in a different genus. Babenko et Fjellberg [2006] used the name Chaetaphorura Rusek, 1976 as the most suitable, but these species only partly fit the diagnosis of Chaetaphorura. Dunger et Schlitt [2011], in their "Synopsis on Palaearctic Collembola. Tullbergiidae", mixed a number of unrelated Nearctic and Palaearctic forms under the name "Nordic group of Tullbergia sensu Fjellberg (1998)" which is obviously not natural. Fjellberg's usage [2015] of the name

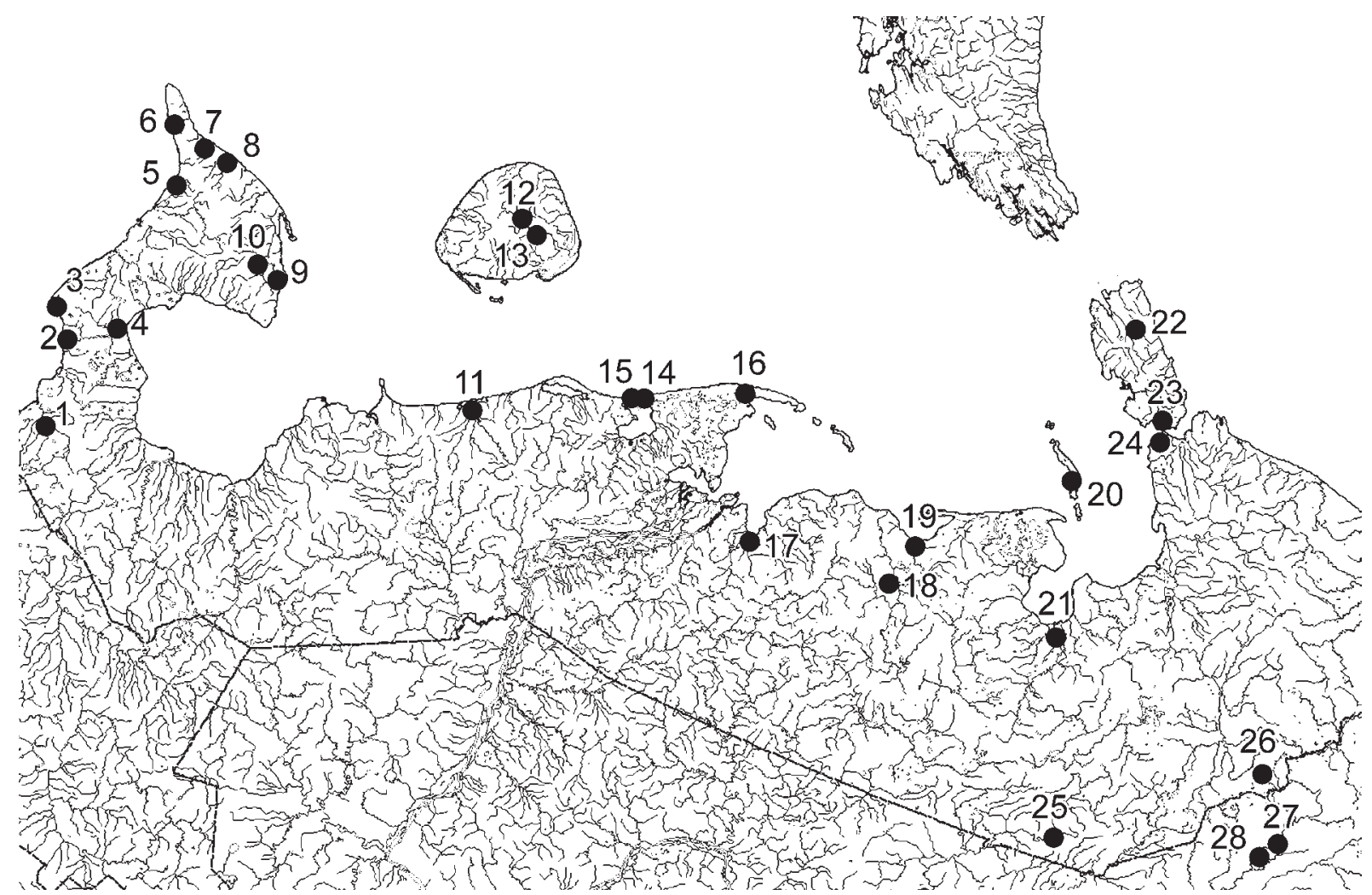

Fig. 1. Localities within the region under consideration (see Table 1 for explanations).

Рис. 1. Рассматриваемые локалитеты региона (см. Таблицу 1 для уточнений). 
Chaetaphorura and the placement of simplex in Mesaphoru$r a$ on www.collembola.org only increase the existing mess. For the sake of stability, we prefer to use the name Tullbergia till the situation is solved.

DISTRIBUTION in the East European tundra. Not especially common arctic-alpine species found both on Arctic islands and in the mainland of the region under consideration $(20,23,27)$.

GENERAL DISTRIBUTION. Holarctic: alpine and arctic Europe, including Svalbard, southern Siberia (mountain tundra of SE Tuva), Alaska and Arctic Canada.

\section{Tullbergia sp.}

TAXONOMIC REMARKS. This is another member of the "Nordic group of Tullbergia" characterized by $A O$ with 2 dorsolateral clubs, labium of the Mesaphorura-type with all five papillae present, 5 long guards, and 6 proximal setae, a simple maxillary palp without sublobal setae, $P A O$ with roundish lobes arranged in 3-4 irregular rows, 11/122/11111 pso of the III type, abundant tibiotarsal chaetotaxy with 15 $(7 A+M+7 B), 15,14$ ( $B_{6}$ absent) setae and $A b d .5$ with crescentic ridges. Among Palaearctic Tullbergiidae, this species appears to be most similar to "Tullbergia" ghilarovi (Khanislamova, 1987) in showing almost identical $P A O$, especially in large individuals, the same type of $p s o$, but distributed as 11/111/11111, identical tibiotarsal chaetotaxy and labium. Both species completely fit the existing diagnosis of Granuliphorura Rusek, 1976, with two known Nearctic species ( $G$. obtusochaeta Rusek, 1976 and G. pomorskii Smolis, 2010), which was sunk into the "Nordic group of Tullbergia" by Dunger et Schlitt [2011]. On the other hand, all these forms also share many diagnostic traits with representatives of the Euro-Asiatic genus Paratullbergia Womerslay, 1930.

DISTRIBUTION in the East European tundra. Scattered records, mainly in soils of rich meadow, not common $(13,19,20)$.

GENERAL DISTRIBUTION. Not known outside the region under consideration.

Wankeliella intermedia Potapov et Stebaeva, 1997

DISTRIBUTION in the East European tundra. Scattered records, not common $(13,17,22)$.

GENERAL DISTRIBUTION. Probably widespread in Palaearctic (described from southern Siberia, later recorded in Taimyr and questionably on Svalbard by Fjellberg [1998]).

\section{Onychiuridae}

\section{Hymenaphorura anatolii Pomorski, 2001}

DISTRIBUTION in the East European tundra. The most common species of the genus in the region, sometimes very abundant in bogs and wet meadows $(12,16,17,18,19,20$, $21,22,23,24,27$ )

GENERAL DISTRIBUTION. Recorded in the northern parts of the Palaearctic from the Kolguev Island to the basin of Yana River [Pomorski, 2001], questionable also in Greenland [Fjellberg, 2015].

\section{Hymenaphorura inopinata Babenko, sp.n.} Figs 2-11.

DIAGNOSIS. A species of the genus Hymenaphorura characterized by the complete absence of sublobal setae on the maxillary our lobe, the second outer papilla in $A O$ usually being furcate, setae $p_{2}$ clearly longer and thicker than $p_{3}$ on $A b d .1-3$, and the unguiculus rather short.

MATERIAL. Holotype, $\sigma^{7}$, Bolshezemel'skaya Tundra, Bolvanskaya Guba, left bank of Yachei River $\left[68.0857^{\circ} \mathrm{N} 54.7833^{\circ} \mathrm{E}\right]$, willow bushes between meadow and bog, 18-24.07.2015. O. Makaro- va and M. Bizin leg.

Paratypes: 9 우 and $14 \sigma^{\top} \sigma^{\top}$, slides, holotype sample.

ADDITIONAL MATERIAL. About 90 specimens, same region, date and collectors, meadow on river bank.

DESCRIPTION. Size 1.5-1.7 mm (+o), 1.2-1.6 mm ( $\left.\sigma^{\top} \sigma^{7}\right)$, holotype length $1.5 \mathrm{~mm}$. Colour white. Habitus typical of genus, body cylindrical, elongate (Fig. 2). Granulation rather coarse and uniform, unclear areas of coarser granulation similar to c2 type of Arbea and Jordana [1994] sometimes distinguishable, but more usually granulation only slightly enlarged on head, around pseudocelli (with 9-11 grains around each pso, Fig. 9) and on dorsal side of Abd.5-6.

Antennae about as long as head. Subapical organite and latero-external $m s$-seta present on Ant.4 in usual position, distinctly thickened s-setae absent. Ant.3 organ typical of the genus (Fig. 4), consisting of four guard setae, 5 (4-6) papillae, two smooth sensory rods, and two granulated sense clubs, ventro-lateral $m s$ present. Second external papilla in $A O$ frequently forked, its shape rather variable (Fig. 6), specimens without or with additional forked papillae also seen (Fig. 5). Ant.1 with 8(9) setae, Ant.2 with 15(14-16) setae.

$P A O$ in a deep narrow groove, usually with 10-12 simple vesicles, set oblique to its long axis (Fig.7), only one border seta present. Labrum with 4 prelabral and 7 labral setae, 4 apical ones clearly longer. Labium of $A$-type, typical of genus with 4 papillae ( $E$ - absent), 5 long and 4 short guards and 6 proximal setae (Fig. 8), basal parts (submentum and mentum) with 4 and 5 setae, respectively. Maxillary palp simple, sublobal hairs absent (Fig. 8).

Dorsal pseudocellar formula as 10/011/11112 (Fig. 3), ventral and subcoxal pso absent. Number and position of parapseudocelli as usual: 1/111/1111 dorsal on postero-lateral corners of terga and $01 / 000 / 111111^{\mathrm{m}}$ ventral, 2 ps $x$ also present on each upper subcoxa, 1 psx on outer side of each coxa, and 1 psx on inner side of each femur. Localization of pseudopores also typical: 0/011/1111 dorsal and 0/111/ $01^{\mathrm{m}} 1^{\mathrm{m}} 1^{\mathrm{m}}$ ventral.

Dorsal chaetotaxy slightly plurichaetotic but usually symmetric in axial parts of terga, macrosetae clearly differentiated only laterally and on abdominal tip (Fig. 3), sensory seta $S$ distinctly visible only on $A b d .5$. Th.1 with 7-9 setae on each side. Th. $2-A b d .4$ with $3+3$ microsetae along midline, Abd.5 with $4+4$ such setae, lateral $m s$ present on Th.2-3. Setae $p_{2}$ on Abd.1-3 thicker and longer than $p_{3}($ ratio $=1.4-1.7)$ (Fig. 9). Only two lateral macrosetae clearly differentiated in $p$-row on granulated field of $A b d .5$ ( 2 additional macrosetae present on each pleurum), $p 2$ usually as mesoseta but sometimes rather long (Figs 10), unpaired axial seta $p_{0}$ absent. Sterna of Th.23 usually with $1+1$, more rarely with $1+2$ or $2+2$ setae along ventral line. $V T$ with $8-10$ distal setae on each side. Furcal field on $A b d .4$ as usual of genus: small, usually subdivided area of finer granulation in mid-section of sterna with 2 posterior "dental" setae. Manubrial row(s) irregular with up to 9 setae between flanked macrosetae.

Legs chaetotaxy: 3, 4-5, 4 setae on upper subcoxae of L.1-3, respectively; 1, 4, 4-5 setae on lower subcoxae; 3-4, 9-13, 12-16 setae on coxae; 8-10, 9, 9 setae on trochanters, and $16-19,15-17,13-14$ setae on femora. Tibiotarsi with complete set: 20, 20, 19 (distal whorl $A+T$ with 11 setae, $M$ seta and $Y$-seta present and $B_{6}$ absent on Ti.3). Unguis simple, without tooth (Fig. 11), unguiculus clearly shorter than half of inner edge of unguis (ca. $0.4 U_{3}$ ). $A S$ strong and curved, about as long as unguis, basal papillae low.

ETYMOLOGY. The name of the new species reflects our surprise after its discovery, from the Latin inopinatus which means unexpected. 


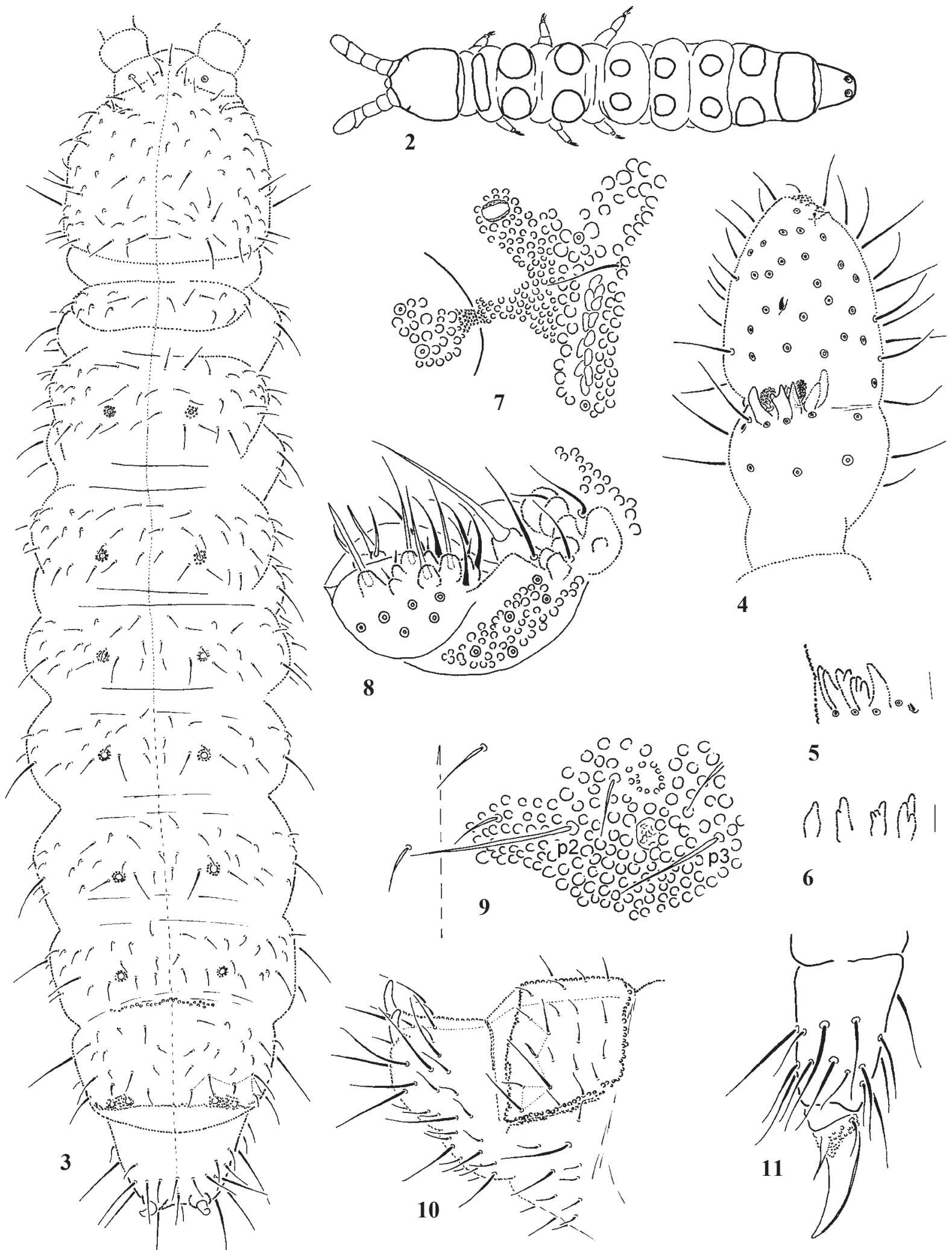

Figs 2-11. Hymenaphorura inopinata sp.n. 2 - general appearance and granulated fields; 3 - chaetotaxy and pso distribution; 4 Ant.3-4;5 - variant of $A O ; 6$ - shape of the second external papilla in $A O$ (different specimens); 7 - PAO and nearest $p$ so; 8 - labium and maxillary outer lobe; 9 - setae of $p$-row on $A b d .2 ; 10$ - abdominal tip; 11 - hind tibiotarsus.

Рис. 2-11. Hymenaphorura inopinata sp.n. 2 - общий вид и поля грануляции; 3 - хетотаксия и расположение ложных глазков; 4 - Ant.3-4; 5 - вариант антеннального органа; 6 - форма второй наружней папиллы в антеннальном органе (разные экземпляры); 7 - постантеннальный орган и ближайший ложный глазок; 8 - нижняя губа и внешняя лопасть максиллы; 9 - хеты $p$-ряда на $A b d .2$; 10 - конец брюшка; 11 - задняя голенелапка. 
AFFINITIES. The most characteristic feature of the new species is the absence of sublobal hairs on the maxillary outer lobe, a unique trait unknown for any other species from the northern Palaearctic, i.e. H. sibirica (Tullberg, 1876), H. polonica Pomorski, 1990, H. anatolii, H. palaearctica Pomorski, 2001, H. similis (Folsom, 1917), H. nearctica Pomorski, 2001, all of which possess two sublobals. This character state has been recorded in all species of the genus described recently, namely $H$. wusuliensis Sun et $\mathrm{Wu}, 2013^{2}$, H. maoerensis Sun, 2014, H. minuta Sun, 2014 H. ioni Buşmachiu et al., 2014, as well as H. nicolae Barra, 1994 (based on paratypes study), apparently being the most typical.

Using Pomorski's key [2001], the new species could be identified as H. teretis Pomorski, 2001, H. aurantiana Weiner et Stomp, 2001 or H. parva Skarżyński et Pomorski, 1996. All these four species share the following set of characters: 10/011/11112 dorsal pso, a forked second external papilla in $A O$, one seta at $P A O$ groove, setae $p 2$ on $A b d .1-2$ subequal to or longer than $p_{3}, 11$ distal setae on tibiotarsi, and unguis with neither inner nor lateral teeth.

H. teretis, described from Alaska, is larger (2.2-2.3 $\mathrm{mm}$ in males and $2.8-3.0 \mathrm{~mm}$ in females $v s \quad 1.2-1.6$ and $1.5-1.7 \mathrm{~mm}$ in $H$. inopinata sp.n.), has a more distinctly differentiated chaetom with 7(8) more or less developed macrosetae on the granulated field of $A b d .5$, more lobes in PAO (15-17 simple or bilobed lobes in H. teretis vs 10-12 simple lobes in $H$. inopinata sp.n.) and a longer unguiculus (4/5 of unguis in $H$. teretis $v s$ less than $1 / 2$ of unguis $H$. inopinata sp.n.).

Two European congeners (H. aurantiana and $H$. parva) are clearly smaller $(0.8-1.2 \mathrm{~mm})$ and characterized by the absence of dorsal psx at the posterior margin of the head and on Th.1 (0/011/1111 psx as a whole) and by a longer unguiculus (3/4 $U_{3}$ in $H$. parva and subequal to unguis in H. aurantiana). The above three species can be also distinguished by the number of macrosetae on the granulated field of Abd.5: 1+1 lateral macrosetae in H. parva, $3+3$ in $H$. aurantiana ${ }^{3}$, and $2+2$ in $H$. inopinata sp.n.

DISTRIBUTION in the East European tundra. The species has only been found in one of the study areas where it was rather abundant and the only representative of the genus in meadows and willow bushes (17).

GENERAL DISTRIBUTION. Not known outside the region under consideration.

\section{Hymenaphorura sibirica (Tullberg, 1876)}

DISTRIBUTION in the East European tundra. Widespread in the region, but less common and abundant than the coexisted $H$. anatolii at least in its western parts, clearly prefers wet meadows and other water-logged habitats $\left(9^{4}, 16\right.$, $19,23,24)$

GENERAL DISTRIBUTION. The species in the recently accepted scope appears to have rather limited range: the easternmost part of the Malozemel'skaya Tundra represents its western boundary whereas the Yenisei River basin the easternmost one [Babenko, 2007].

2 The date of the original description of this species [2011] given on www.collembola.org is erroneous.

3 3 3 macrosetae were mentioned in Discussion part of the original description, whereas the main body stated “... on abdominal tergite $V$ seta al (short macroseta), a4 (short macroseta), $p 2$ and p5 as macrosetae".

4 This old record of the species by Linnaniemi [1909] from the Kanin Peninsula obviously requires verification.
Micraphorura absoloni (Börner, 1901)

DISTRIBUTION in the East European tundra. More common in the southern parts of the region under study, rarely also in warmer sites in the north $(10,11,25,26,27)$.

GENERAL DISTRIBUTION. Trans-Holarctic.

Oligaphorura groenlandica (Tullberg, 1876)

DISTRIBUTION in the East European tundra. Common and widespread in the region, clearly preferring more humid sites than the following congener $(11,12,16,17,19,22,23,27)$.

GENERAL DISTRIBUTION. Northern Holarctic.

Oligaphorura ursi (Fjellberg, 1984)

DISTRIBUTION in the East European tundra. Common and usually more polytopic than the previous species, occurring not only in water-logged sites, but in a wide range of habitats $(11,12,13,17,19,20,22,23,24,27)$.

GENERAL DISTRIBUTION. Most probably circumpolar, although there is no verified records from northern Canada.

Megaphorura arctica (Tullberg, 1876)

DISTRIBUTION in the East European tundra. Still only a few records of the species in the region under study $(11,20)$.

GENERAL DISTRIBUTION. Northern Europe, including Novaya Zemlya, Svalbard, Iceland, and Greenland.

Protaphorura bicampata (Gisin, 1956)

DISTRIBUTION in the East European tundra. Common in the region, generally preferring rather lush habitats like herbaceous meadows and different bushes $(17,18,20,24,25,26,27)$.

GENERAL DISTRIBUTION. Palaearctic.

Protaphorura boedvarssoni Pomorski, 1993

TAXONOMIC REMARKS. Pomorski [1993] gave the following formulas for the species: $33 / 022 / 33342$ in the diagnosis (and in fig. 11) but 33/022/33332 in Description and 33(2)/022/33332(3) in the Variability part. We have never seen any specimens with 3 pso on $A b d .4$ and most probably this is just a mistake. On the contrary, the number of posterior pso on the head and, especially, that on $A b d .5$ is rather variable within the region, the variant with 33/022/ 33343 pso being the most common.

DISTRIBUTION in the East European tundra. Probably the most usual, abundant and polytopic species of the genus in the region under study $(10,11,12,13,15,17,18,19,20$, $21,22,24,25,26,27)$.

GENERAL DISTRIBUTION. Northern Europe.

Protaphorura borealis (Martynova, 1973)

DISTRIBUTION in the East European tundra. Only a single record in the easternmost part of the region (27).

GENERAL DISTRIBUTION. Previously known from Novaya Zemlya to Alaska [MacLean et al., 1978; Babenko, Kaprus', 2014].

\section{Protaphorura jacutica (Martynova, 1976)}

DISTRIBUTION in the East European tundra. Widespread in the region but usually not especially abundant (10, $12,13,16,17,18,19,20,22,23,24,25,26,27)$.

GENERAL DISTRIBUTION. Central Palaearctic from the Kanin Peninsula in the west to northern Buryatia [Gulgenova, Potapov, 2013] in the east.

\section{Protaphorura macfadyeni (Gisin, 1953)}

TAXONOMIC REMARKS. A typical P. macfadyeni, " $a$ characteristic species in marine littoral wrack and beach 
meadows" of Northern Norway [Fjellberg, 1998, p. 118] and Kola Peninsula [Babenko, 2012], occurs in the region under consideration $^{5}$ together with a very similar form characterized by the following set of characters: $4,2-3 / 022-3 / 3-4,3-$ 4,3,4-5,3-4 dorsal pso [43/023/33353 being most common]; ventral pso $1 /-$; subcoxae $1-1-1$; PAO with 20-24 lobes; Th. 1 with $10-12+10-12$ setae, $m$ absent (i2-3-); unguis with a more or less clear inner tooth; $A b d .1-3$ rather often with, Abd.5 always without, $s$ ' setae; prespinal setae subparallel; $M / s=16-19 / 11-13, A S=10$. In other words, this $P$. cf. macfadyeni differs from the available descriptions of the typical macfadyeni [Fjellberg, 1998; Kaprus', Pomorski, 2008] by the chaetotaxy of Th.1 ( $m$-seta present in the typical form), the presence of $s$ ' setae on Abd.1-3 (variable in cf. macfadyeni, always absent in the typical form) and the unguis with inner tooth (always without tooth in the typical form).

DISTRIBUTION in the East European tundra. A single record of the typical form (16) and a few ones of $P$. cf. macfadyeni along the seashore $(20,21,24)$, a single inland record (26) requires confirmation.

GENERAL DISTRIBUTION. Northern Europe, including Iceland, Svalbard and Greenland.

Protaphorura pjasinae (Martynova, 1976)

DISTRIBUTION in the East European tundra. Babenko et Kaprus' [2014] named Dolgii Island as the westernmost distributional limit of the species. In fact it is rather widespread and even common in the northern parts of Bolshezemel'skaya Tundra $(17,18,19,20,21,22,23,24)$.

GENERAL DISTRIBUTION. East Palaearctic - Nearctic.

Protaphorura pseudovanderdrifti (Gisin, 1957)

DISTRIBUTION in the East European tundra. A single record in the southern part of the region (25).

GENERAL DISTRIBUTION. Europe, including Iceland and Greenland [Fjellberg, 2007b, 2015]

Protaphorura salsa Kaprus', Paśnik, Weiner, 2014

DISTRIBUTION in the East European tundra. A rare species with only a few records within the region $(16,17)$.

GENERAL DISTRIBUTION. This is the second record of the species after its original description based on material from Novosibirsk Region, Siberia.

\section{Protaphorura stogovi Pomorski, 1993}

DISTRIBUTION in the East European tundra. Scattered records all over the region, sometimes rather abundant (11, $15,18,26,27)$

GENERAL DISTRIBUTION. Known only from Eastern Europe with the Karelian coast of the White Sea being the westernmost range limit.

\section{Protaphorura subarctica (Martynova, 1976)}

DISTRIBUTION in the East European tundra. Common and can be rather abundant at least in the northern parts of the region $(10,11,12,13,16,17,18,19,20,21,22,23,24,27)$.

GENERAL DISTRIBUTION. Palaearctic, excluding Western Europe [Babenko, Kaprus', 2014].

Protaphorura subuliginata (Gisin, 1956) sensu Fjellberg, 1998

DISTRIBUTION in the East European tundra. Only few samples from two remote areas: Kolguev Island $(12,13)$ and

\footnotetext{
Erroneously recorded from the region as $P$. vanderdrifti (Gisin,
} 1952) by Babenko et Fjellberg [2006] the vicinity of Vorkuta (27).

GENERAL DISTRIBUTION. Europe including Iceland and Greenland.

Protaphorura taimyrica (Martynova, 1976)

DISTRIBUTION in the East European tundra. Only two records in the easternmost part of the region $(22,23)$.

GENERAL DISTRIBUTION. Previously recorded from the Novaya Zemlya Archipelago in the west to the Magadan Province in the east [Babenko, Kaprus', 2014].

Protaphorura tundricola (Martynova, 1976)

DISTRIBUTION in the East European tundra. Widespread in the region, usually preferring rather dry and warmer habitats $(16,17,18,20,21,22,23,24)$.

GENERAL DISTRIBUTION. Still known only from the Central Palaearctic (from Severnaya Dvina to the Yenisei basin).

\section{Protaphorura vasilinae}

Kaprus', Weiner et Paśnik, 2016

DISTRIBUTION in the East European tundra. Only a single record from the upper part of maritime marsh (21).

GENERAL DISTRIBUTION. Previously known only from the vicinity of Novosibirsk and NE Altai.

\section{Supraphorura furcifera (Börner, 1901)}

DISTRIBUTION in the East European tundra. Common and widespread, clearly preferring wet habitats $(13,16,17$, $18,19,20,21,22,23,24,25,26,27)$.

GENERAL DISTRIBUTION. Palaearctic.

Thalassaphorura duplopunctata (Strenzke, 1954)

DISTRIBUTION in the East European tundra. Only few records from seashore places $(20,23)$.

GENERAL DISTRIBUTION. Palaearctic.

Uralaphorura schilovi (Martynova, 1976)

DISTRIBUTION in the East European tundra. Common and widespread in the region, sometimes rather numerous $(17,18,19,20,21,22,27)$.

GENERAL DISTRIBUTION. Northern Europe.

Deuteraphorura variabilis (Stach, 1954)

DISTRIBUTION in the East European tundra. Not especially common, but can be abundant in ornithogenic substrates $(11,15,23,25,27)$.

GENERAL DISTRIBUTION. The majority of West European records, including recent ones from Svalbard [Coulson et al., 2013, 2015], originated from unnatural sites such as flowerpot or composts, although the type material includes specimens collected in "Jednaczewo-forest, on a mushroom". Nevertheless, the species appears to be a usual soil-dweller in northeastern Europe [Pomorski, Skarżyński, 1995; Taskaeva, 2005; Taskaeva, Nakul, 2010].

\section{Hypogastruridae}

Schoettella ununguiculata (Tullberg, 1869)

DISTRIBUTION in the East European tundra. Few records in the southernmost part of the region $(25,26)$.

GENERAL DISTRIBUTION. Holarctic.

\section{Hypogastrura assimilis Krausbauer, 1898}

DISTRIBUTION in the East European tundra. Not frequent, only a single verified record within the region (26).

GENERAL DISTRIBUTION. Considered cosmopolitan. 


\section{Hypogastrura concolor (Carpenter, 1900)}

DISTRIBUTION in the East European tundra. Common in the northern parts of the region, clearly preferring sites enriched in organic matter $(12,20,22)$.

GENERAL DISTRIBUTION. Circumpolar without nonArctic records.

\section{Hypogastrura fjellbergi \\ Babenko et Bulavintsev, 1993}

DISTRIBUTION in the East European tundra. A single record in the easternmost part of the region (20).

GENERAL DISTRIBUTION. East Palaearctic - West Nearctic (Alaska). No records outside the Arctic.

Hypogastrura lapponica (Axelson, 1902)

DISTRIBUTION in the East European tundra. Only a few scattered records $(19,20,25,27)$.

GENERAL DISTRIBUTION. Palaearctic, a boreal species rarely penetrating into the true tundra.

Hypogastrura litoralis (Axelson, 1907)

DISTRIBUTION in the East European tundra. Still only the old record by Linnaniemi [1909] from the region (6).

GENERAL DISTRIBUTION. Northwestern Europe, a littoral form.

\section{Hypogastrura purpurescens (Lubbock, 1867)}

DISTRIBUTION in the East European tundra. Only few specimens in a barnacle goose nest (13).

GENERAL DISTRIBUTION. Cosmopolitan, including Iceland and Greenland.

Hypogastrura tullbergi (Schäffer, 1900)

DISTRIBUTION in the East European tundra. Common both in dry and wet habitats, especially in the northern parts of the region $(19,20,21,22,23)$.

GENERAL DISTRIBUTION. Circumpolar, but still found neither in northern Canada nor Greenland.

\section{Hypogastrura viatica (Tullberg, 1872)}

DISTRIBUTION in the East European tundra. Rather common on marine shores, as well as in inland sites, especially those enriched in organic matter $(11,14,15,16,21,23$, 24).

GENERAL DISTRIBUTION. Cosmopolitan.

Cosberella navicularis (Schött, 1893)

DISTRIBUTION in the East European tundra. A few scattered records, but sometimes very abundant $(19,21,27)$

GENERAL DISTRIBUTION. Central parts of the northern Palaearctic (from the Pechora River basin to northern Yakutia).

Ceratophysella cf. armata (Nicolet, 1842)

TAXONOMIC REMARKS: Fjellberg [1998, p. 40] in the Discussion part concerning C. longispina, stated that "In our area the species [i.e. C. longispina] is the only Arctic species of group B. It is similar to the European C. armata which does not occur in the Nordic countries...". In contrast, in the northeastern parts of Russia and further to the east such specimens "differing mainly by the quality of the hair cover which in armata is much finer with relatively longer sensilla, in particular on the last abdominal tergites" do exist. We are, however, not sure that they are conspecific with European C. armata; only genetic studies could probably resolve the problem in the future.
DISTRIBUTION in the East European tundra. Common, but usually not numerous $(12,17,19,21,22,23,24)$.

GENERAL DISTRIBUTION. Considered Holarctic, but confused due to taxonomic problems.

Ceratophysella czelnokovi Martynova, 1978

C. brevis (Christiansen et Bellinger, 1980) sensu Babenko et al., 1994 TAXONOMIC REMARKS: Martynova's original description of the species was based on 3 specimens from Wrangel Island which were characterized by strongly thickened, rather short dorsal setae and the absence of axial $m_{1}$ setae on $A b d .4$. In fact the latter character appears to be rather variable and most of the specimens studied from the same area show the usual chaetotaxy of $A b d .4$ with all axial setae $\left(a_{1}, m_{1}\right.$, and $\left.p_{1}\right)$ present in a slightly divergent position. Similar dark coloured specimens from the denticulata-group found on the Taimyr Peninsula and characterized by small differences between the anterior and posterior lobes of $P A O$, thickened and rather short dorsal setae and thin dental ones were treated by Babenko et al. [1994] as C. brevis (Christiansen et Bellinger, 1980). It is widely distributed along the northern coast at least of the Eastern Palaearctic, clearly preferring wet and cold habitats; its identity with Alaskan specimens treated as C. brevis remains problematic.

DISTRIBUTION in the East European tundra. Only a few records from the northern parts of the region $(22,24)$.

GENERAL DISTRIBUTION. East Palaearctic - [?] Nearctic.

\section{Ceratophysella denticulata (Bagnall, 1941)}

DISTRIBUTION in the East European tundra. Common, but only rarely especially abundant $(10,13,17,18,19,20$, $21,23,24,25,26,27)$

GENERAL DISTRIBUTION. Considered as cosmopolitan including Greenland, but most probably several cryptic genetic forms are involved even in northern regions [Pocro et al., 2014].

\section{Ceratophysella longispina (Tullberg, 1976)}

DISTRIBUTION in the East European tundra. Common all over the region, in particular in its northern parts $(12,13$, $15,16,18,19,20,22,24,27)$.

GENERAL DISTRIBUTION. An arctic species with a semi-circumpolar pattern, as verified records are absent from northern Canada and Greenland [Fjellberg, 2015].

Ceratophysella palustris Martynova, 1978

DISTRIBUTION in the East European tundra. Widespread in the region, occurring mainly in different types of bog, often together with C. scotica and C. longispina $(12,13$, $15,16,19,20,22,23,24,27)$.

GENERAL DISTRIBUTION. Northern Palaearctic (excluding Fennoscandia and Kola Peninsula) - West Nearctic (Alaska).

Ceratophysella scotica (Carpenter et Evans, 1899)

DISTRIBUTION in the East European tundra. In waterlogged habitats all over the region $(11,16,17,19,20,21)$.

GENERAL DISTRIBUTION. Mainly northern Europe, with Yamal Peninsula as the easternmost record.

\section{Ceratophysella succinea (Gisin, 1949)}

DISTRIBUTION in the East European tundra. Common, but not as abundant as previous species $(17,18,19,20,23,24)$. 
GENERAL DISTRIBUTION. Cosmopolitan [?], including Svalbard and Greenland.

Choreutinula inermis (Tullberg, 1871)

DISTRIBUTION in the East European tundra. Not typical of the region, the single published record (26) appears to be erroneous.

GENERAL DISTRIBUTION. Palaearctic, a boreal species.

Schaefferia czernovi (Martynova, 1978)

TAXONOMIC REMARKS. This species (together with Typhlogastrura shtanchaevae Abdurakhmanov et Babenko, 1991) has been synonymized by Thibaud et al. [2004] with $S$. quinqueoculata (Yosii, 1956), the latter form described from Japanese caves, because "the three taxa have same chaetotaxy and the same morphological characters". This may be true, although in our view a final decision can only be made after a modern redescription of $S$. quinqueoculata, because the existing ones are obviously outdated. As regards two other forms, i.e. S. czernovi and T. shtanchaevae, they clearly belong to two very distinct units, for instance, due to chaetom differentiation which is quite different.

DISTRIBUTION in the East European tundra. All over the region, both in dry and wet habitats, never especially abundant $(12,17,18,19,20,21,27)$.

GENERAL DISTRIBUTION. East Palaearctic.

Willemia anophthalma Börner, 1901

DISTRIBUTION in the East European tundra. The most numerous and common species of the genus in the region, as all other congeners clearly prefers warmer and lush habitats $(13,17,18,19,20,24,25,27,28)$.

GENERAL DISTRIBUTION. Holarctic, records from the southern hemisphere require verification.

\section{Willemia denisi Mills, 1932}

DISTRIBUTION in the East European tundra. Common, but not as abundant as the previous species $(10,12,13,19$, $20,23,24,27)$

GENERAL DISTRIBUTION. Holarctic.

Willemia intermedia Mills, 1934

DISTRIBUTION in the East European tundra. Probably a species rare in the region, as there is only a single record (13)

GENERAL DISTRIBUTION. Holarctic, including Iceland and Svalbard, with some doubtful southern records

Willemia scandinavica Stach, 1949

DISTRIBUTION in the East European tundra. Probably widespread, but still only few verified records $(17,18)$.

GENERAL DISTRIBUTION. Holarctic.

Willemia similis Mills, 1934

DISTRIBUTION in the East European tundra. A species with a clear preponderance to the Arctic, more frequent in the northern parts of the region $(12,13,19,20,22,23,24,27)$.

GENERAL DISTRIBUTION. Holarctic, in Western Europe only Iceland and Svalbard.

Willemia trisphaerae Potapov, 1994

DISTRIBUTION in the East European tundra. A single verified record (19).

GENERAL DISTRIBUTION. Central part of the Palaearctic; described from the Kola Peninsula, also known from several remote regions of Siberia, including the Altai and
Sayan mountains [Babenko et al., 1994] and the northern taiga in the Yenisei River basin [Babenko, 2007]).

Xenylla brevicauda Tullberg, 1869

DISTRIBUTION in the East European tundra. Only Linnaniemi's old record in the southern part of the region (1).

GENERAL DISTRIBUTION. Europe, a boreal species.

Xenylla humicola (Fabricius, 1780)

DISTRIBUTION in the East European tundra. Common in salt marine marshes and organic debris on the seashore, often rather abundant $(4,8,15,18,19,20,21,24)$.

GENERAL DISTRIBUTION. Cosmopolitan, a littoral form.

Xenylla maritima Tullberg, 1869

DISTRIBUTION in the East European tundra. A single verified record (10).

GENERAL DISTRIBUTION. Cosmopolitan.

\section{Brachystomellidae}

Brachystomella parvula (Schäffer, 1896)

DISTRIBUTION in the East European tundra. Probably all over the region, clearly preferring hydromorphic habitats $(16,18,19,20,21,22,24,26,27)$.

GENERAL DISTRIBUTION. Considered cosmopolitan.

\section{Neanuridae}

Friesea claviseta Axelson, 1900

DISTRIBUTION in the East European tundra. Infrequent $(18,20,27)$.

GENERAL DISTRIBUTION. Cosmopolitan.

Friesea mirabilis (Tullberg, 1871)

DISTRIBUTION in the East European tundra. Common all over the region $(10,15,18,20,22,23,24,25,27,28)$.

GENERAL DISTRIBUTION. Cosmopolitan.

Friesea quinquespinosa (Wahlgren, 1900)

DISTRIBUTION in the East European tundra. Infrequent in the region, with only several sporadic records (19, 20,23).

GENERAL DISTRIBUTION. Holarctic, no records outside the Arctic.

Friesea truncata Cassagnau, 1958

DISTRIBUTION in the East European tundra. The most abundant and polytopic species of the genus in the region (11, $12,13,15,16,17,18,19,20,21,23,25,26,27)$.

GENERAL DISTRIBUTION. Trans-Palaearctic.

Gisinea subtilia Babenko, sp.n.

$$
\text { Figs 12-27. }
$$

DIAGNOSIS. Species of the genus Gisinea characterized by a full number of ocelli.

MATERIAL. Holotype, + , Barents Sea, Vaigach Isl., vicinity of Varnek [69.6923 $\left.{ }^{\circ} \mathrm{N} 60.1669^{\circ} \mathrm{E}\right]$, herbaceous coast meadow, 8.07.2015. A. Babenko leg.

Paratypes: 2 우 and $O^{\prime}$, Barents Sea, Dolgii Isl. [69.2236 ${ }^{\circ} \mathrm{N}$ $59.2378^{\circ} \mathrm{E}$ ], zonal plant community, 11.07.2004. O. Makarova leg.; $1 \mathrm{O}^{7}$, same area, stony beach with Silene acaulis, 04.07.2004. O. Makarova leg.; 1 ㅇ, $1 \mathrm{O}^{7}$ and 2 juveniles, Pakhanchenskaya Guba $\left[68.4839^{\circ} \mathrm{N} 57.2172^{\circ} \mathrm{E}\right]$, herbaceous meadow, 26.075.08.2015. O. Makarova and M. Bizin leg.; 4 우, Khaipudyrskaya Guba $\left[68.355^{\circ} \mathrm{N} 59.9297^{\circ} \mathrm{E}\right]$, maritime marsh with Carex subspatacea, Salix reptans, Calamagrostis deschampsioides, 6- 


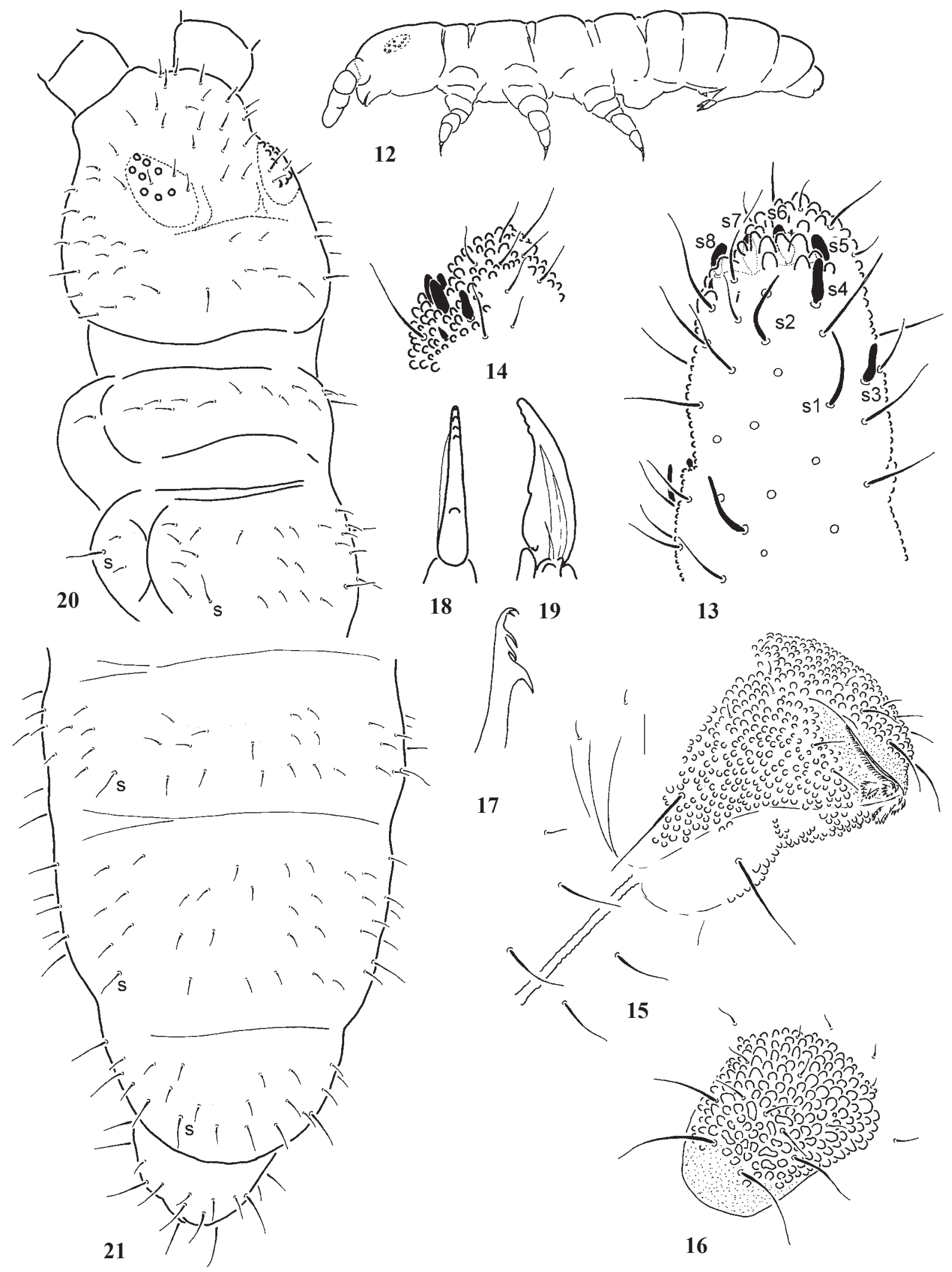

Figs 12-21. Gisinea subtilia sp.n. 12 - general appearance; $13-14$ — antennal tip; 15 — chaetotaxy of buccal cone; 16 - labrum; 17 mandible tip; 18-19 - maxillary head (different views); 20 - chaetotaxy of head and Th.1-2; 21 - chaetotaxy of Abd.3-6.

Рис. 12-21. Gisinea subtilia sp.n. 12 - общий вид; 13-14 - конец антенны; 15 - хетотаксия ротового конуса; 16 - верхняя губа; 17 - конец мандибулы; 18-19 - головка максиллы (с разных сторон); 20 - хетотаксия головы и Th.1-2; 21 — хетотаксия $A b d .3-6$. 
16.08.2015. O. Makarova and M. Bizin leg.

ADDITIONAL MATERIAL. 1 juvenile, Arkhangelsk Oblast, Pinega State Nature Reserve, vicinity of Golubino $\left[64.5547^{\circ} \mathrm{N}\right.$ 43.2654 ${ }^{\circ} \mathrm{E}$ ], Dryas and Arctous cover on cliffs, 21.09.2004, O Makarova leg.; 1 juvenile, Komi Republic, Pechoro-Ilychski Nature Reserve, sand beach of Pechora River, 13.07.2009, M. Potapov leg.; 1 juvenile, northern part of Krasnoyarsk Krai, vicinity of Turukhansk $\left[65.8305^{\circ} \mathrm{N} 88.0952^{\circ} \mathrm{E}\right]$, damp graminous meadow, 2.08.2003, A. Babenko leg.; 3 females and 3 juveniles, South-Western Yakutia, Lenskii region, Chayanda River, 2011, V. Boeskorov leg.

DESCRIPTION. Size up to $2.3 \mathrm{~mm}$, holotype $1.8 \mathrm{~mm}$, mature males from $1.4-1.5 \mathrm{~mm}$. Colour rather light, greyish-blue, eye fields darker. Habitus typical of the genus (Fig 12), anal spines absent. Tegument granulation rather coarse and regular, cuticular granules on abdominal tip high and conical.

Antennae about as long as head diagonal. Apical vesicle variable, but usually 2 or 3-lobed, Ant.3-4 fused dorsally, blunt s-setae on Ant.4 clearly differentiated: six of them flame-like, thick and blunt $\left(S_{3}-S_{8}\right)$, two others $\left(S_{1}-S_{2}\right)$ thin and curved, poorly distinguishable from ordinary setae (Figs 13-14), tiny peg-like subapical organite and $m s$ present in usual positions. Ant.3 organ typical with two small inner, two longer outer s-setae and ventro-lateral $m s$. Ant. 1 and 2 with a basic (for Poduromorpha) set of setae, i.e. (6)7 and (12)13 setae, respectively.

Head with a full set of ocelli $(8+8)$, cornea subequal and rather small. $P A O$ absent. Buccal cone strong and protruding (Fig. 15). Labrum with 4 prelabral and 12 labral setae, four subapical ones the longest (Fig. 16). Labium with a finely serrate fringe at anterior edge and $2+2$ peculiar subapical papillae and a highly reduced chaetotaxy of $6+6$ setae. Using D'Haese's [2003] nomenclature, these could be regarded as proximal setae $a_{1}$ and $a_{2}$ on main part of labium, macroseta $F$ on submentum and 3 microsetae (? e, d, and c) on mentum (Fig. 15). 2+2 rather long postlabial setae present along ventral mid line, other ventral setae on head short and fine. Mandibles thin, weakly sclerotized, usually with two small apical and three basal teeth (Fig. 17). Maxillary capitulum triangular, with several poorly visible subapical teeth at edge and a fine membranous lamella (a basal spine on capitulum seen in few cases can represent a second lamella) (Figs 18-19).

Dorsal chaetotaxy more or less symmetrical and rather peculiar for Poduromorpha, but not for the genus (Figs 20$21)$. Head with complete rows $d$ and $s d$ on area frontalis, as well as a posterior row $p$. On the contrary, rows $c$ partly and $v$ completely reduced and the number of lateral setae clearly increased. Th.1 with 6-7 setae on each side, arranged almost in line. Th.2-3 usually with 5 setae in each row in a slightly irregular position ( $m_{2}$ absent, $p_{4}$ and $m_{6}$ being ssetae), but a seta missing or duplication rather frequent. Lateral $m s$ present only on metathorax. Abd.1-3 with 3+3 axial setae $\left(m_{1}\right.$ present, s-setae $\left.p_{5}\right), 4+4$ axial setae present on $A b d .4$ and $3+3$ such setae on $A b d .5$ ( $m$ present, s-setae $\left.p_{3}\right)$. Thoracic sterna without setae along ventral line.

Number of setae on Leg.1-3, respectively: upper subcoxae - 1, 2, 3; lower subcoxae - 0, 3, 3; coxae - 3-4, 8, 78; trochanters - 5, 5, 4-6; femora - 12, 11, 10; tibiotarsi 12, 12, 11 ( $T$ setae, $A_{4}, A_{5}$, and seta $M$ absent from all legs, Ti.3 also lack $B_{6}$ ). Most setae on legs slightly thickened, few thin and long ones present on femora and trochanters (Fig. 22). Unguis toothless.

$V T$ with 5(6) setae on each side. Tenaculum with $3+3$ teeth. Furca rather long (dens + mucro/ $\left.U_{3}=1.4-1.6\right)$ and complete (Figs 23-24), dens with 5 subequal posterior setae, mucro clearly separated, about as long as $0.25-0.35$ dens. Completely mature males with several modified setae on sterna of $\mathrm{Abd.3-4}$ (Figs 25-26). In immature males these setae thickened but longer and not serrated (Fig. 27).

ETYMOLOGY. The name reflects the high similarity of the new species to $G$. tilia Babenko, 1998, the main reason for a long time lag between its discovery in 1998 and the present description.

AFFINITIES. Formally, the new species should be treated as a representative of the genus Tremoisea Cassagnau, 1973, but not Gisinea Massoud, 1965. In having a full set of ocelli, it fits the existing diagnosis of the former genus clearly better. Nevertheless, it is so similar to $G$. tilia, the only notable distinctive character of which being a reduced number of ocelli $(6+6)$, that it is hardly possible to put them in two different genera.

Both genera share a number of traits which are not only characteristic of other Frieseinae as well, but unique in Neanuridae. Among the latter, a peculiar position of s-setae on Ant.4, a prolonged buccal cone with subapical papillae and an odd and similar chaetotaxy, the presence of setae $m_{1}$ on $A b d .4-5$, the position of s-setae on the abdominal terga ( $p_{5}$ on $A b d .1-3, p_{4}$ on $A b d .4$ and $p_{3}$ on $A b d .5$ ) are the most extraordinary. Thus, Tremoisea and Gisinea obviously belong to the same evolutionary lineage and could probably be even synonymized. Nevertheless, for the sake of stability we prefer to retain both genera and look for additional characters that can distinguish them regardless of the number of ocelli.

The former genus is purely Mediterranean, with three known species, i.e. T. enigmatica Cassagnau, 1973, T. ossica Cassagnau, 1973, and T. israelica Gruia et al., 1999, all are soil-dwelling. The latter genus was originally established for $G$. delhezi Massoud, 1965, from a Belgian cave, but later one Siberian soil species, G. tilia, was added. All species of Tremoisea are characterized by an almost identical dorsal chaetotaxy pattern with a set on the thorax usual for Neanuridae (s-setae in $p_{3}$ and $m_{6}$ position, only lateral setae of $m$-row present), but not on abdomen. In contrast, the dorsal chaetotaxy of three Gisinea species with three (or four on $\mathrm{Abd.4}$ ) rows of setae on all terga from $T h .2$ to $A b d .5$ is unique for Poduromorpha both on the thorax and abdomen. Therefore, the diagnosis of the Gisinea can be redefined emphasizing the importance of chaetotaxy over the number of ocelli as "a genus of Frieseinae characterized by a prolonged, beak-shaped buccal cone, the absence of AS and the presence of complete furca and $\mathrm{m} 1$-setae on all terga from Th.2 to Abd.5".

There are also some other differentiating characters, for instance, the shape and number of s-setae on Ant.4 (5 cylindrical s-setae in all known Tremoisea vs 6 or more strongly thickened ones in Gisinea) or tibiotarsal chaetotaxy which, however, is variable in Tremoisea (two species with a complete set, i.e. 19, 19, 18, and reduced one in T. ossica, i.e. 15, $15,14)$. All three species of Gisinea have a strongly reduced set of setae on tibiotarsi $(12,12,11$ in tilia and subtilia, delhezi according to fig. 2B in Massoud [1965] has only 10 setae on Ti.3). Their value as diagnostic characters at generic level is probably lower.

DISTRIBUTION in the East European tundra. Common and rather polytopic, but never abundant $(17,19,20,21,22$, $23,24)$.

GENERAL DISTRIBUTION. Probably widespread in the Eastern Palearctic, found in several remote regions from Eastern Europe to Eastern Siberia. 


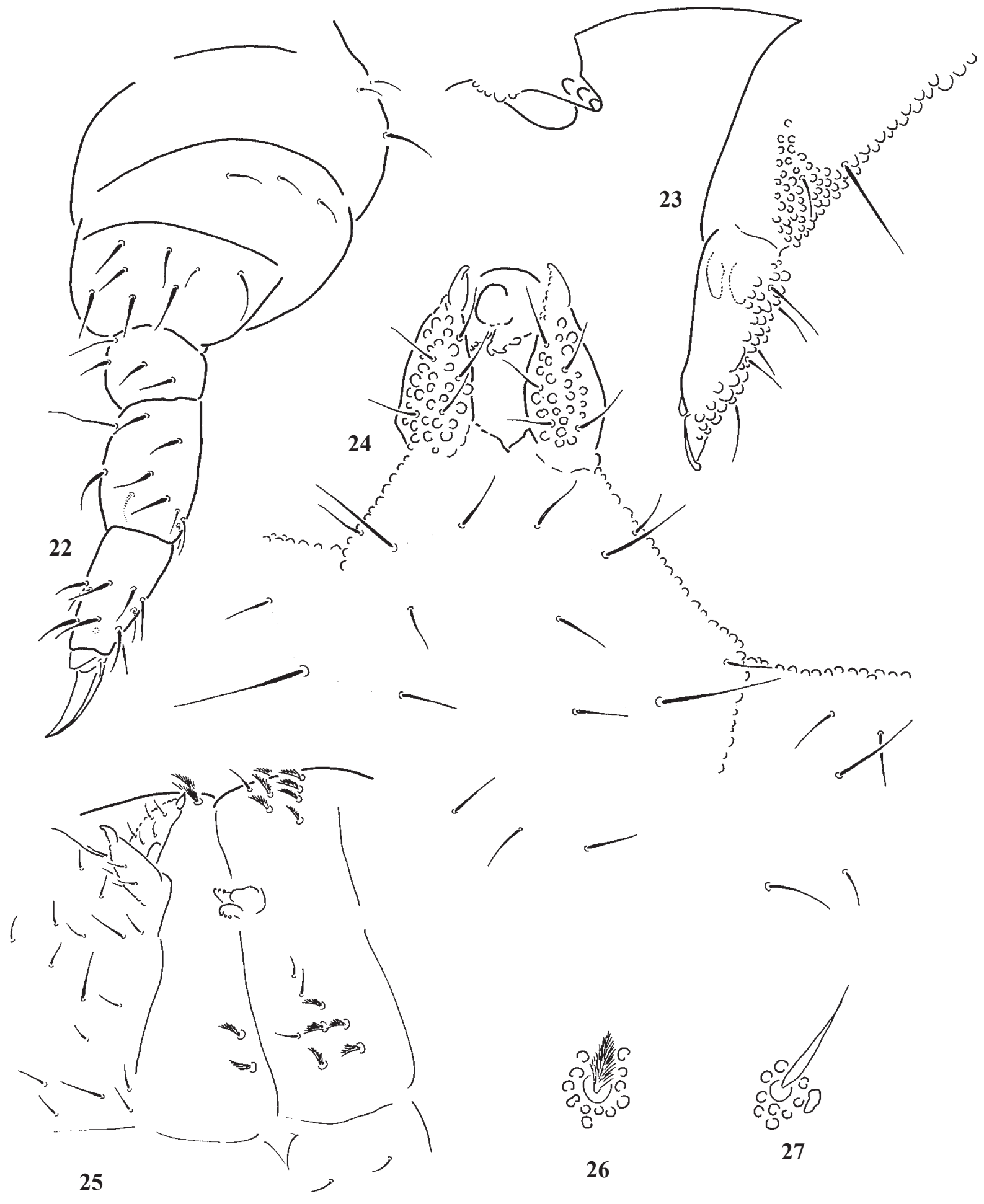

Figs 22-27. Gisinea subtilia sp.n. 22 - chaetotaxy of hind leg; 23 - furca and tenaculum (lateral view); 24 - ibid. (ventral view); 25 modified setae on sterna of $A b d .3-4 ; 26$ - shape of modified setae in mature male; 27 — ibid., immature male.

Рис. 22-27. Gisinea subtilia sp.n. 22 - хетотаксия задней ноги; 23 - прыгательная вилка и зацепка (сбоку); 24 - то же (снизу); 25 - модифицированные хеты на стернитах $A b d .3-4 ; 26$ - форма модифицированных хет у половозрелого самца; 27 - то же, у неполовозрелого самца. 
Micranurida pygmaea Börner, 1901

DISTRIBUTION in the East European tundra. Common and sometimes rather abundant $(10,12,13,15,17,18,19,20$, $22,23,24,25,26,27)$.

GENERAL DISTRIBUTION. Mainly Holarctic (including Iceland, Svalbard and Greenland) with a few southern records.

\section{Anurida alpina Agrell, 1939}

DISTRIBUTION in the East European tundra. Several sporadic records in hydromorphic sites such as marine marshes and snowbeds $(17,21,22,23)$.

GENERAL DISTRIBUTION. Palaearctic, an arctic species occurring in the south only in alpine habitats.

Anurida azurea Babenko, 1997

DISTRIBUTION in the East European tundra. Not especially common, only several scattered records are available $(17,18,19,21)$.

GENERAL DISTRIBUTION. East Palaearctic, non-Arctic records are still absent.

\section{Anurida beringi Fjellberg, 1985}

DISTRIBUTION in the East European tundra. This characteristic species of the Beringian hammerae-group is registered almost all over the northern belt of the region never being abundant $(17,18,19,20,21,22,23,25,27)$.

GENERAL DISTRIBUTION. Palaearctic (excluding West Europe) - Northern Nearctic.

\section{Anurida dynkengda Babenko, 1998}

DISTRIBUTION in the East European tundra. Registered only once on the Kolguev Island (13) being rather common in the available material (present in 11 of 18 soil samples).

GENERAL DISTRIBUTION. The species has hitherto been recorded only from the northern part of the Yenisei River basin.

\section{Anurida ellipsoides Stach, 1949}

DISTRIBUTION in the East European tundra. The most numerous and widespread species of the genus occurring all over the region $(10,11,13,17,18,19,20,21,22,23,24,26,27)$.

GENERAL DISTRIBUTION. Europe with the Yamal Peninsula as the easternmost range limit.

Anurida komi Babenko, 1998

DISTRIBUTION in the East European tundra. Probably a southern element in the regional fauna, found only at its southern border $(25,26,27)$.

GENERAL DISTRIBUTION. It appears to be rather limited, with only a few records within the forested part of the Komi Republic [Kolesnikova et al., 2010; Gomina, 2015].

Anurida palustris Babenko, 1997

DISTRIBUTION in the East European tundra. Common in most parts of the region, usually preferring wet communities $(16,17,19,20,21,22)$.

GENERAL DISTRIBUTION. From the Kola Peninsula in the west to the Taimyr Peninsula in the east, there is still no record outside the Arctic.

Anurida papillosa (Axelson, 1902)

DISTRIBUTION in the East European tundra. Common all over the region, but usually not abundant $(3,6,11,12,13$, $15,16,17,18,19,20,21,22,23,24,26)$.
GENERAL DISTRIBUTION. From Karelia to Buryatia [Gulgenova, per. comm.]

Anurida polaris (Hammer, 1954)

DISTRIBUTION in the East European tundra. A single record of the species in the region under consideration (20).

GENERAL DISTRIBUTION. Circumpolar, an Arctic species with a few mountainous records outside the Arctic.

Anurida subarctica Fjellberg, 1985

DISTRIBUTION in the East European tundra. Only a few records within the region $(12,24)$.

GENERAL DISTRIBUTION. Almost trans-Holarctic, excluding Western Europe, Greenland and Canada.

Anurida thalassophila (Bagnall, 1939)

DISTRIBUTION in the East European tundra. A littoral species probably distributed all along seashore $(19,20,21,22)$.

GENERAL DISTRIBUTION. Europe, including Iceland, Svalbard and Greenland.

Pseudachorutes dubius Krausbauer, 1898

DISTRIBUTION in the East European tundra. A boreal species with a few remote records in the region $(10,25,26,27)$.

GENERAL DISTRIBUTION. Europe.

Pseudachorutes parvulus Börner, 1901

DISTRIBUTION in the East European tundra. Uncommon $(17,20)$

GENERAL DISTRIBUTION. Palaearctic, mainly a corticole species with most of the recent records from Europe. The presence of the species in Central and Southern America [Mari Mutt, Bellinger, 1990] probably requires confirmation.

\section{Pseudachorutes sibiricus Rusek, 1991}

DISTRIBUTION in the East European tundra. Scattered records all over the region, not abundant $(12,13,16,18,19$, 20).

GENERAL DISTRIBUTION. East Palaearctic, the northern Nearctic records (mainly as subcrassoides Mills) are problematic.

Pseudachorutes subcrassus Tullberg, 1871

DISTRIBUTION in the East European tundra. A single record in the southern belt of the region (26).

GENERAL DISTRIBUTION. Palaearctic, a forest species ascending to lower alpine habitats; records from South America are dubious [Mari Mutt, Bellinger, 1990].

Morulina gigantea (Tullberg, 1876)

DISTRIBUTION in the East European tundra. A single record of this Siberian species at the westernmost corner of Bolshezemel'skaya Tundra (17) lies more than $400 \mathrm{~km}$ west of that of Linnaniemi [1919] in the Kara River basin. Known also from the vicinity of Vorkuta (27).

GENERAL DISTRIBUTION. East Palaearctic.

Endonura reticulata (Axelson, 1905)

DISTRIBUTION in the East European tundra. Common and rather polytopic all over the region $(16,17,18,19,20,21$, $25,26,27$.

GENERAL DISTRIBUTION. Palaearctic, excluding West Europe - Alaska [Smolis et al., 2011], a typical inhabitant of the southern tundra belt, but most records are from forest sites. 
Neanura muscorum (Templeton, 1835)

DISTRIBUTION in the East European tundra. A forest species rarely penetrated into the tundra belt $(3,5,18,25,27)$.

GENERAL DISTRIBUTION. Considered Holarctic, with a number of records from Central and Southern America, southern Africa, India, Australia and New Zealand, but its occurrence even in Siberia appears to be problematic.

\section{Odontellidae}

Xenyllodes armatus Axelson, 1903

DISTRIBUTION in the East European tundra. Common, rather polytopic and sometimes abundant $(10,11,15,17,18$, $19,20,22,23,24,26,27)$.

GENERAL DISTRIBUTION. A boreal species, common all over the Holarctic.

\section{Isotomidae}

Agrenia bidenticulata (Tullberg, 1876)

DISTRIBUTION in the East European tundra. Probably widespread in the region, although only two remote records along the marine shore are still present $(7,24)$.

GENERAL DISTRIBUTION. A circumpolar Holarctic species recorded also from the alpine belt of European mountains.

\section{Agrenia riparia Fjellberg, 1986}

DISTRIBUTION in the East European tundra. Only few scattered records for the region $(10,11,15,25,26)$.

GENERAL DISTRIBUTION. A boreal species with a vast Holarctic distribution range.

\section{Anurophorus fjellbergi Potapov, 1997}

DISTRIBUTION in the East European tundra. A single record on the Dolgii Island (20).

GENERAL DISTRIBUTION. A northern species with an eastern Palaearctic distributional pattern, Chukotka serving as the easternmost region.

Anurophorus septemtrionalis Pallissa, 1966

DISTRIBUTION in the East European tundra. A single record in the southern belt of the region (26), which can be erroneous.

GENERAL DISTRIBUTION. A boreal species with an Eastern European distributional pattern, being absent both from Denmark and western parts of Norway [Fjellberg, 2007a] and from Asiatic part of Russia [Potapov, Stebaeva, 1990].

Archisotoma besselsi (Packard, 1877)

DISTRIBUTION in the East European tundra. Common all along sea shores $(19,20,21)$.

GENERAL DISTRIBUTION. A typical littoral form with a Holarctic distributional pattern.

\section{Desoria alaskensis (Fjellberg, 1978)}

DISTRIBUTION in the East European tundra. Not especially common and abundant, mostly in damp sites $(19,27)$.

GENERAL DISTRIBUTION. East Palaearctic - Nearctic. In Alaska, mainly a boreal species penetrating the tundra belt, in the Palaearctic previously known only in the eastern sector of the Arctic, from Chukotka to northern Urals [Taskaeva, 2005; Gomina, 2015]).

Desoria atkasukiensis (Fjellberg, 1978)

DISTRIBUTION in the East European tundra. All over the region in various damp sites $(10,17,18,19,20,24)$.
GENERAL DISTRIBUTION. Widely distributed in the Arctic with a general pattern similar to the one in the previous species, already recorded in East European tundra [Babenko, Fjellberg, 2006].

\section{Desoria blufusata (Fjellberg, 1978)}

DISTRIBUTION in the East European tundra. Common, but not especially abundant $(10,11,17,18,21,24,25)$.

GENERAL DISTRIBUTION. A widespread hydrophilic species with a Holarctic distribution range.

\section{Desoria breviseta Potapov, sp.n.} Figs 28-44.

DIAGNOSIS. Species of the tigrina-group characterized by a specific structure of the maxilla with a long and expanded lamella 1 covered by several distinct rows of long cilia.

MATERIAL. Holotype, + , Russia, NE of European part, Nenetsky Autonomous Okrug, Barents Sea, Vaigach Island (south), Vicinity of Varnak, $\left[69.69^{\circ} \mathrm{N} 60.17^{\circ} \mathrm{E}\right]$, plant debris at bank of river mouth, 8.07.2015, A. Babenko leg.

Paratypes: 5 specimens, same place.

ADDITIONAL MATERIAL. Dolgii Island, $69.22^{\circ} \mathrm{N} 59.24^{\circ} \mathrm{E}$, 17.07.2004, O. Makarova leg.; Kola Peninsula, Barents Sea coast, vicinities of Dal'niye Zelentsy, $69.12^{\circ} \mathrm{N} 36.05^{\circ} \mathrm{E}, 07.2009$, A. Babenko leg.; Spitsbergen, Barentsburg $\left(78.04^{\circ} \mathrm{N} 14.13^{\circ} \mathrm{E}, 08.07 .2011\right)$ and Piramiden $\left(78.41^{\circ} \mathrm{N} 16.24^{\circ} \mathrm{E}, 16.07 .2012\right)$, S. Coulson leg.; Taimyr, mouth of Uboinaya River, 07.1988, A. Babenko leg.; Taimyr, mouth of Ragozinka River, 07.1983, A. Babenko leg.; northern Yakutia, delta of Indigirka River, Russko-Ustinskaya Protoka, 07.1994. A. Babenko leg.; Chukotka, vicinities of Lavrentiya, $65.58^{\circ} \mathrm{N} 171.00^{\circ} \mathrm{E}, 29.07 .2013$, O. Makarova and A. Babenko leg.

DESCRIPTION. Body size up to $1.8 \mathrm{~mm}$. Colour bluish grey. $P A O$ narrow, elongate, 2.4-3.2 times as long as diameter of nearest ocellus (Fig. 36). Ant.1 with 5-8 thickened pointed $s$-setae and few thin ones in ventro-lateral position. Ant. 2 and Ant. 3 with numerous thin and few thickened $s$-setae (Figs 29, 30). Apical pin-seta of Ant.4 clearly bifurcate. Subapical organite small, rod-shaped. Prelabral setae 4. Labrum with common 14 setae and simple ventro-apical ciliation, its apical edge without distinct apical folds (Fig. 34). Labial palp without guard $e_{7}$, guards $e_{5}$ and $e_{6}$ enlarged, guards $b_{3}$ and $b_{4}$ same length as $b_{1}$ and $b_{2}$ (Fig. 31, 32). Proximal and median fields of labium with 4 and 4 setae, respectively. Maxilla as in Fig. 35. Maxillary head with a slender capitulum, lamella 1 long and broad, with clear 4-5 rows of cilia, lamellae 2 and 4 slightly passing beyond tip of capitulum, lamella 6 narrow. Outer maxillary lobe with 4 sublobal hairs and simple palp (Fig. 33). Head with 6-9 postlabial setae.

Ordinary tergal setae subequal, smooth and short; macrosetae poorly differentiated, median pair of $A b d .50 .4-0.5$ as long as tergum and about as long as inner length of last unguis; macrosetae usually slightly thickened at the middle, but the character varies (Fig. 37). Dorsal $s$-setae numerous, scattered over most part of each tergum, accp s-setae (5-8 in number on each tergum from $T h .2$ to $A b d .4$ ) normally set in front of $p$-row on thorax and within $p$-row on abdomen. Some accp $s$-setae (more frequently on anterior segments) moved forward (set in front of $p$-row) and formally the number of $s$ setae within $p$-row on Th.2-Abd.4 can be expressed as $0,0-2 /$ 2-6,3-6,3-7,7-8 (Fig. 28). Only Th.2 and Abd.3 with $m s$ setae present $(10 / 001$ as a whole) .

$V T$ with 5-9+5-9 frontal, 4(5)+4(5) latero-distal and 610 posterior setae with 4 in the apical transverse row (Fig. 39). Retinaculum with 7-9 setae. Manubrium with common ventro-apical manubrial teeth and $2+2$ short ventro-apical setae (Fig. 38). Dens with numerous posterior crenulations, 

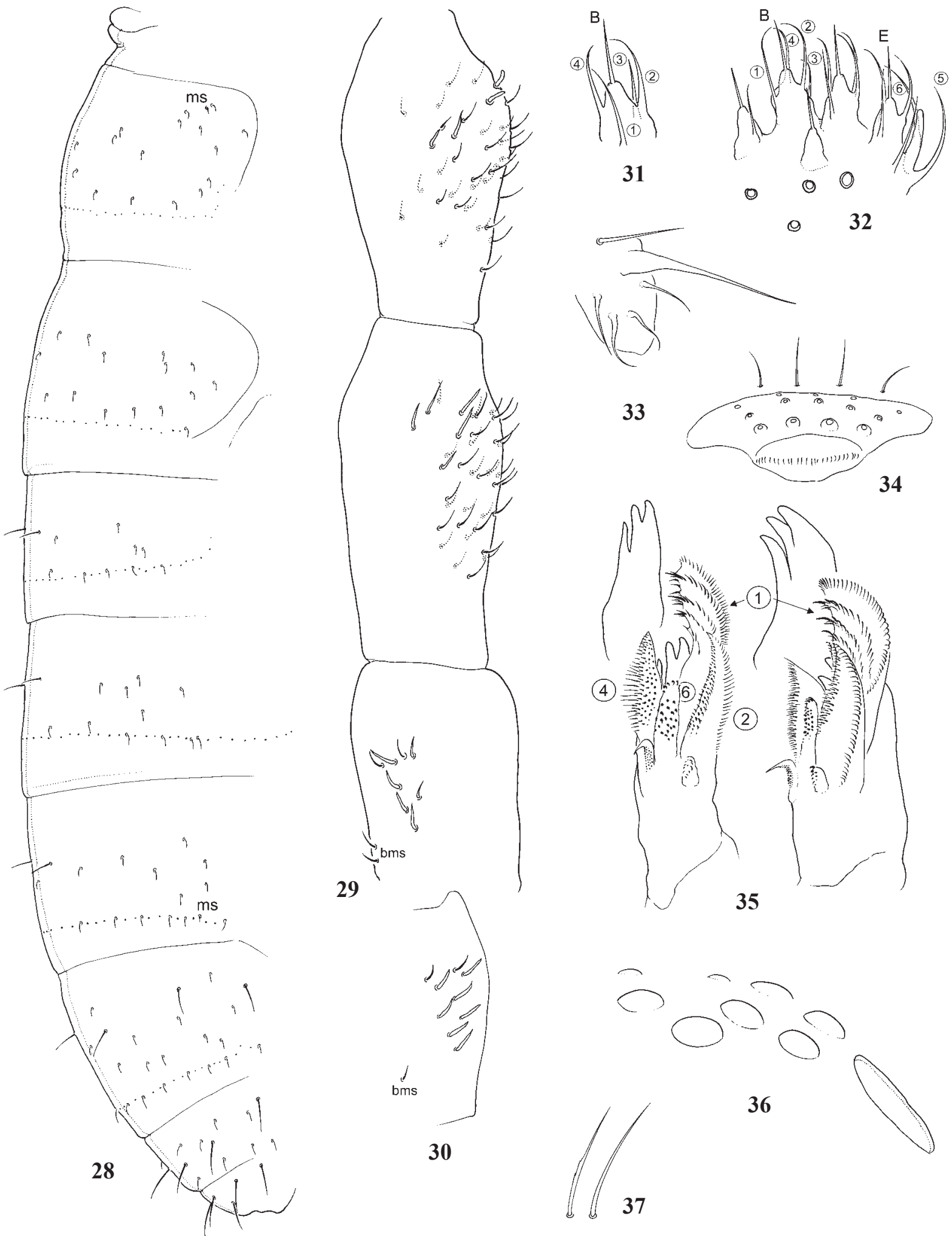

Figs 28-37. Desoria breviseta sp.n. 28 - one of the variants of $s$-setae, $m$ s-setae, macro- and $p$-row setae on body tergites; 29 - $s$-setae of Ant.1-3; 30 - s-setae of Ant.1, another specimen; 31 - labial palp; 32 - papilla $B$; 33 - maxillary outer lobe; 34 - labrum, ventral view; 35 - maxillary head (different views); 36 - PAO and ocelli; 37 - macrosetae of $A b d .5$ (variation).

Рис. 28-37. Desoria breviseta sp.n. 28 - один из вариантов расположения $s$-хет, $m$ s-хет, макро- и хет $p$-ряда на тергитах тела; $29-s$-хеты Ant.1-3; $30-s$-хеты Ant.1, другой экземпляр; 31 - нижнегубная пальпа; 32 - папилла $B$; 33 - наружняя лопасть максиллы; 34 - верхняя губа, снизу; 35 - головка максиллы (с разных сторон); 36 - постантеннальный орган и глазки; 37 макрохеты $A b d .5$ (изменчивость). 
many anterior and 16-22 posterior setae (Fig. 40). Apical tooth of mucro larger than subapical one (Fig. 43). Unguis with lateral and inner teeth (Figs 41, 42). Upper subcoxa of first leg with one, lower subcoxa with one, more rarely, two outer setae.

ETYMOLOGY. The name of the new species reflects the size of tergal macrosetae, from the Latin brevis meaning "short".

AFFINITIES. D. breviseta sp.n. is a member of the tigrina-group sensu Fjellberg [2007a] characterized by the absence of mucronal seta together with a simple maxillary palp. The modern understanding of D. tigrina Nicolet, 1942, the nominative species of the group, is based on Fjellberg's [1979] treatment who re-established it from "Isotoma olivacea" auct. Recently, the same author [2007a] has shown that it consists of several related forms differing in the structure of mouthparts. As a result, two morphologically rather distinct forms, i.e. D. tigrina sensu Fjellberg, 2007 and D. grisea (Lubbock, 1869) sensu Fjellberg, 2007, exist now despite their sympatric ranges and ecological similarity. D. breviseta sp.n. is the third member of the same complex which differs from both others primarily by the shape of maxillary head: distal part of Lam.1 in D. breviseta sp.n. is expanded and covered by several distinct rows of long cilia, in the two other species the same lamella is also long, but not so broad and its "inner face with dense cover of coarse, curved denticles, not clearly arranged in rows" [Fjellberg, 2007a, p. 129, figs $72 \mathrm{E}-72 \mathrm{~F}]$. All other morphological characteristics, namely, a simple maxillary palp, weak apical folds on labium, an increased number of $s$-setae on antennae and terga, the presence of thickened $s$-setae on Ant.1, a similar type of the furca, and short dorsal macrosetae, point to a close relationship of all three congeners. The labium of $D$. breviseta sp.n. is more similar to that in D. tigrina: guards $b_{3}$ and $b_{4}$ of normal length (strongly reduced in $D$. grisea), $e_{5}$ and $e_{6}$ prolonged, although to a lesser extent than in $D$. grisea (of normal length in D.tigrina). D. breviseta sp.n. is also characterized by the shortest dorsal macrosetae among the group members: 0.4

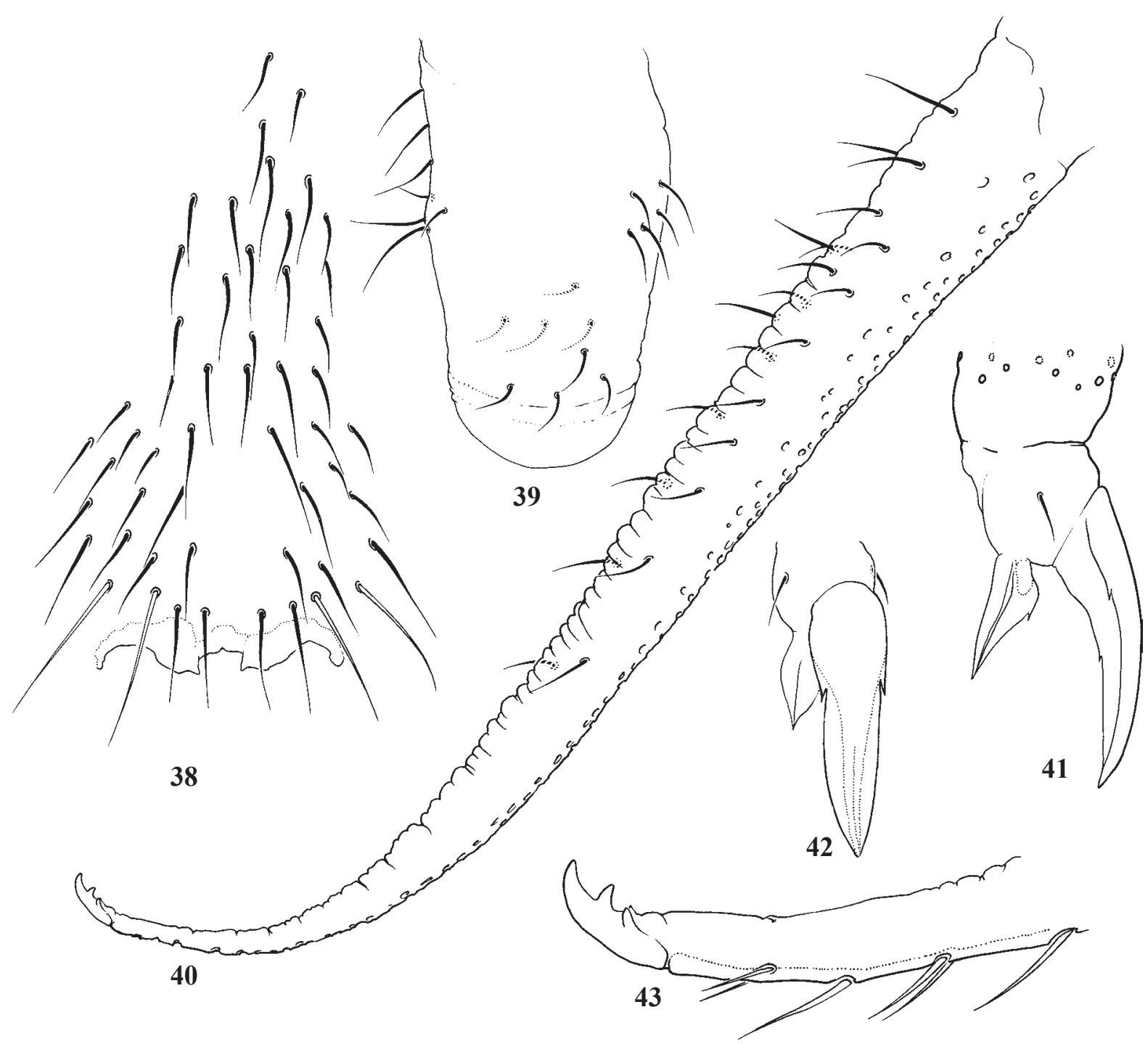

Figs 38-43. Desoria breviseta sp.n. 38 - anterior side of manubrium; 39 - ventral tube (lateral view); 40 - dens (anterior setae not shown); 41 - apical part of leg (front view); 42 - ibid., (lateral view); 43 - apical part of furca.

Рис. 38-43. Desoria breviseta sp.n. 38 - передняя сторона манубрия; 39 - брюшная трубка (сбоку); 40 - денс (передние хеты не показаны); 41 — конец ноги (спереди); 42 - то же, (сбоку); 43 - концевая часть прыгательной вилки. 


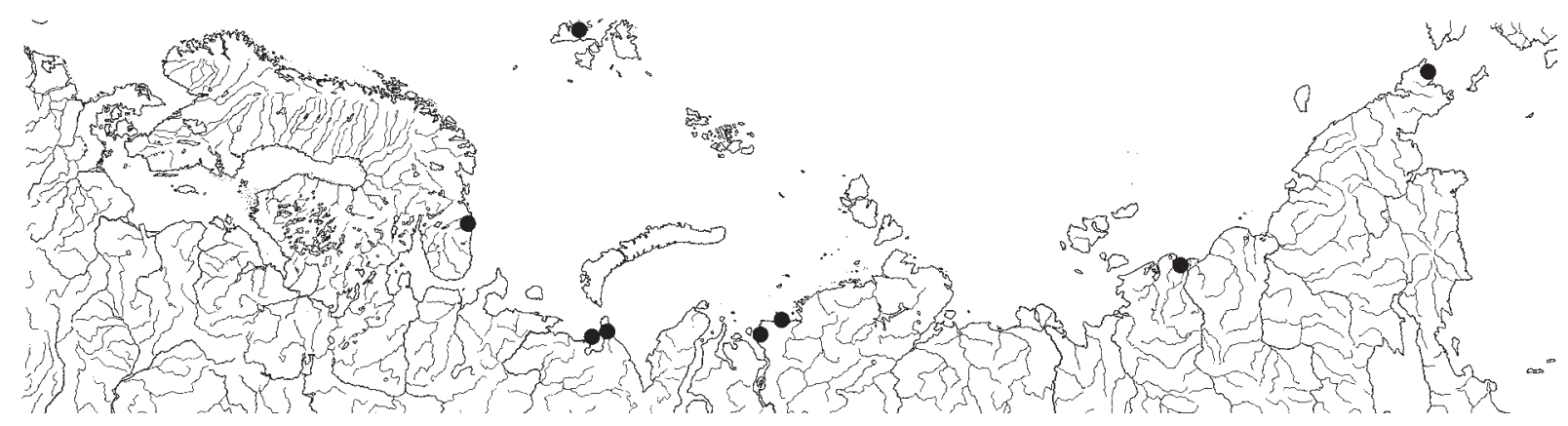

Fig. 44. Desoria breviseta sp.n. Map of distributional pattern. Рис. 44. Desoria breviseta sp.n. Карта распространения.

0.5 as long as $A b d .5$ tergum and subequal to inner edge of $U_{3}$ vs $0.6-0.8$ and about twice as long as $U_{3}$ ). Both features, i.e. expanded maxillary lamella and short setae, point to a more hygrophilous mode of life of the new species which more or less corresponds to the available ecological evidence.

The only other known species of the genus which shows a similar structure of the maxilla (Lam.1 with several rows of cilia) is D. maxillosa (Fjellberg, 1978), described from the central part of the U.S.A. (Illinois). This Nearctic species probably belongs to the same group, but differs considerably from $D$. breviseta sp.n. in many characters, for instance, the mucro shape (the apical tooth is smaller than the subapical one in D. maxillosa, but clearly larger in D. breviseta sp.n.), only 2 setae in the apical row of the posterior setae on $V T$ in D. maxillosa vs 4 such setae in D. breviseta sp.n., brush-like ciliation of the labrum in D. maxillosa vs a simple one in D. breviseta sp.n., and some fine details of maxillary structure are also differ.

DISTRIBUTION in the East European tundra. Usually in organic debris on seashores $(20,23)$.

GENERAL DISTRIBUTION. Uncertain due to confusion with related forms, but at least the northern Palaearctic (Fig. 44), probably including Greenland [Fjellberg, 2015, as a shorthaired form of D. tigrina] and imported soils on Svalbard [Coulson et al., 2015, as tigrina]. In the Palaearctic this species has also been referred to as $D$. sp.aff. maxillosa by Babenko [2003] and Desoria sp.A by Babenko et Fjellberg [2006].

\section{Desoria fennica (Reuter, 1895)}

DISTRIBUTION in the East European tundra. A few scattered records from the Arctic Islands within the region, not abundant $(13,20,22,23)$.

GENERAL DISTRIBUTION. A hygrophilous Palaearctic species ranging from Iceland and Norway to Mongolia.

Desoria hiemalis (Schött, 1893)

DISTRIBUTION in the East European tundra. Not common, only a few records in the southern parts of the region $(3$, 26, 27).

GENERAL DISTRIBUTION. A boreal species widespread in North and Central Europe, including the European part of Russia, the existing records from other regions needs confirmation.

Desoria neglecta (Schäffer, 1900)

DISTRIBUTION in the East European tundra. The most common and abundant Desoria species occurring all over the region $(2,3,5,6,10,11,12,13,16,17,18,19,20,21,23,24,27)$.

GENERAL DISTRIBUTION. A hygrophilous Holarctic species.
Desoria olivacea (Tullberg, 1871)

DISTRIBUTION in the East European tundra. Not common, only a few scattered records $(10,13,17,18)$.

GENERAL DISTRIBUTION. Uncertain because it had frequently been confused with other species before Fjellberg's revision [1979]. The most recent verified records are from Europe including, Greenland, Iceland, and Svalbard where the species coexists with the more numerous and closely related $D$. tshernovi.

Desoria propinqua (Axelson, 1902)

DISTRIBUTION in the East European tundra. Not common, but can be rather abundant in substrates enriched in organic matter $(13,22,23,24)$.

GENERAL DISTRIBUTION. Probably trans-Holarctic.

Desoria tolya Fjellberg, 2007

DISTRIBUTION in the East European tundra. Scattered records all over the region, usually not abundant $(10,11,15$, $16,20,24,27)$.

GENERAL DISTRIBUTION. Northern Europe, including Greenland, but not Svalbard.

Desoria tshernovi (Martynova, 1974)

DISTRIBUTION in the East European tundra. Common and abundant in all kinds of damp habitats all over the region $(10,11,12,13,15,17,18,19,20,21,24,27)$.

GENERAL DISTRIBUTION. A circumpolar species with a few records outside the Arctic.

Desoria violacea (Tullberg, 1876)

DISTRIBUTION in the East European tundra. Common and widespread in the region $\left(10^{6}, 12,13,17,18,19,20,21\right)$.

GENERAL DISTRIBUTION. Eastern Palaearctic northwestern Nearctic, it appears to be absent from Western Europe; a published record from Iceland [Fjellberg, 2007b] probably belongs to D. tolya [Fjellberg, pers. comm.].

Folsomia amplissima Potapov et Babenko, 2000

DISTRIBUTION in the East European tundra. Common and can be abundant, especially in the eastern parts of the region $(16,17,18,19,20,21,23,24,26,27)$.

GENERAL DISTRIBUTION. Widely distributed in the eastern parts of the northern Palaearctic up to Chukotka.

\footnotetext{
6 There is also old Linnaniemi's records from the Kanin Peninsula $(3,6)$ as Isotoma violacea $\mathrm{f}$. principalis which may belong to the same modern species
} 
Folsomia atropolaris Potapov et Babenko, 2000

DISTRIBUTION in the East European tundra. A single record in the northeastern part of the region (22).

GENERAL DISTRIBUTION. The northeastern Palaearctic up to the Wrangel Island in the east.

Folsomia binoculata (Wahlgren, 1899)

DISTRIBUTION in the East European tundra. A few records in the northern belt of the region $(20,22,24)$.

GENERAL DISTRIBUTION. Within the Palaearctic most common on Arctic Islands, but also known from hardwood sites of Pechoro-Ilychskii State Nature Reserve, Komi Republic [Gomina, 2015]; also frequently recorded from the mainland along the Asiatic coast of the Arctic Ocean.

Folsomia bisetosa Gisin, 1953

DISTRIBUTION in the East European tundra. Common and can be abundant in a variety of habitats all over the region $(10,11,12,13,15,16,17,18,19,20,21,22,23,24,27)$.

GENERAL DISTRIBUTION. A circumpolar species, most of the old records outside the Arctic need confirmation.

Folsomia bisetosella Fjellberg, 2005

DISTRIBUTION in the East European tundra. Only two records within the region $(20,23)$.

GENERAL DISTRIBUTION. Palaearctic, including Greenland, Iceland, Svalbard and the Wrangel Island.

Folsomia borealis Potapov et Babenko, 2000

DISTRIBUTION in the East European tundra. A hygrophilous species common all over the region $(10,16,17$, 19, 20, 22, 24).

GENERAL DISTRIBUTION. A boreal species with an East Palaearctic distribution pattern, up to the Severnaya Dvina River basin in the west.

Folsomia ciliata Babenko et Bulavintsev, 1993

DISTRIBUTION in the East European tundra. Probably widespread in the region, but most records from its eastern parts $(16,17,19,20,22,23,24,27)$.

GENERAL DISTRIBUTION. Northern Palaearctic, including the northern Urals [Gomina, 2015], still no records from the mainland of Fennoscandia, but recently found on Svalbard [Fjellberg, pers. comm.].

Folsomia continentalis Potapov et Dunger, 2000

DISTRIBUTION in the East European tundra. Only two records in the eastern part of the region $(20,24)$, in both cases rather abundant.

GENERAL DISTRIBUTION. Previously known only from mountain forests in continental Asia (Mongolia, Tuva, Khakassia, Zabaikal'e).

Folsomia cryptophila Potapov et Babenko, 2000

DISTRIBUTION in the East European tundra. Only two samples from ornithogenic substrates on the Vaigach Island (22).

GENERAL DISTRIBUTION. Palaearctic up to Chukot$\mathrm{ka}$ in the east, still not found in Fennoscandia.

Folsomia diplophthalma (Axelson, 1902)

DISTRIBUTION in the East European tundra. Widespread all over the region, but usually not abundant $(2,4,18$, 20, 22, 23, 24, 26).

GENERAL DISTRIBUTION. A Palaearctic species with a limited range: definitely recorded only in the northern regions of Russia (Karelia, Archangelsk District, Komi Re- public, Taimyr, Putorana plateau, Yenisei and Yana River basins), old records outside this area probably erroneous.

Folsomia dovrensis Fjellberg, 1976

DISTRIBUTION in the East European tundra. A single record from the vicinity of Vorkuta (27), probably requires confirmation.

GENERAL DISTRIBUTION. A European species, widely distributed in Fennoscandia [Fjellberg, 2007a], known also from Iceland [Fjellberg, 2007b], the Czech Republic [Rusek, 1980] and the Kola Peninsula [Babenko, 2012].

Folsomia inoculata Stach, 1947

DISTRIBUTION in the East European tundra. A single record in the vicinity of Vorkuta (27), uncommon.

GENERAL DISTRIBUTION. Trans-Palaearctic, probably excluding the westernmost areas of Europe.

Folsomia longidens Potapov et Babenko, 2000

DISTRIBUTION in the East European tundra. Common in various damp sites all over the region $(12,13,15,16,17$, $18,19,20,21,22,23,24,27)$.

GENERAL DISTRIBUTION. Scattered records over the arctic regions of the Palaearctic from Kolguev Island to Chukotka, not found in Fennoscandia, including Svalbard.

Folsomia manolachei Bagnall, 1939

DISTRIBUTION in the East European tundra. Very common and often dominant in a wide range of habitats all over the region $(10,11,13,16,17,18,19,20,21,22,23,24,25,27)$.

GENERAL DISTRIBUTION. Probably all over the Palaearctic.

Folsomia microchaeta Agrell, 1939

DISTRIBUTION in the East European tundra. A single record from the Kolguev Island (12).

GENERAL DISTRIBUTION. An arcto-alpine species with a presumably circumpolar distribution, recorded from northern Norway and Sweden [Fjellberg, 2007a], all along the Arctic coast of Russia (from Kolguev to Wrangel Islands), and in Arctic Canada [Potapov, 2001].

Folsomia palaearctica Potapov et Babenko, 2000

DISTRIBUTION in the East European tundra. Common and rather abundant in a wide range of sites $(10,11,12,13$, $15,17,18,19,20,22,23,24,25,27)$.

GENERAL DISTRIBUTION. A presumably Holarctic species with arctic and alpine preferences.

Folsomia quadrioculata (Tullberg, 1871)

DISTRIBUTION in the East European tundra. The most abundant and widespread species of the genus in the region $\left(1,2,3,4,5,6^{7}, 10,11,12,13,15,16,17,18,19,20,21,22\right.$, $23,24,25,26,27,28)$.

GENERAL DISTRIBUTION. Trans-Holarctic.

Folsomia rossica Potapov et Dunger, 2000

DISTRIBUTION in the East European tundra. Rather common for the region $(12,13,17,18,19,20,22,24,25$, 27).

GENERAL DISTRIBUTION. Widespread in the eastern parts of the Palaearctic (from Mongolia to southern Taimyr), west to the Kola Peninsula [Potapov, Dunger, 2000].

\footnotetext{
Old records of the species (1-6) by Linnaniemi may also belong to F. manolachei
} 
Folsomia sexoculata (Tullberg, 1871)

DISTRIBUTION in the East European tundra. A common inhabitant of the marine littoral zone $(16,19,20,21,23)$.

GENERAL DISTRIBUTION. All along European and Asiatic coasts of the Palaearctic, including Iceland, Greenland, Svalbard, and the Northern island of Novaya Zemlya.

Folsomia taimyrica Martynova, 1973

DISTRIBUTION in the East European tundra. Only two records in the northern parts of the region $(18,20,24)$.

GENERAL DISTRIBUTION. A high Arctic species known from Svalbard, Russian Arctic Archipelagos, Yamal, Taimyr, Wrangel Isl., and many other areas along the Arctic Ocean coast [Potapov, Babenko, 2000].

\section{Folsomia thalassophila Bagnall, 1940}

DISTRIBUTION in the East European tundra. A single verified record for the region (20).

GENERAL DISTRIBUTION. Another exclusive marine littoral form previously known only from Norway, Iceland, Greenland, the Faroes, the British Isles [Fjellberg, 2007a], Germany [Potapov, 2001], and the Kola Peninsula [Babenko, 2012].

\section{Hemisotoma bibasiosetis}

(Potapov et Stebaeva, 1999)

DISTRIBUTION in the East European tundra. A single record for the region (19).

GENERAL DISTRIBUTION. Presumably widespread in the Palaearctic, but only a few remote records still present. Described from mountains of southern Siberia, where it is a characteristic species of the forested steppe belt, later recorded only in the European North of Russia [Babenko, 2012].

Isotoma anglicana Lubbock, 1873

DISTRIBUTION in the East European tundra. Most probably all over the region $(16,17,19,20,21,27)$.

GENERAL DISTRIBUTION. Presumably trans-Palaearctic, including such northern areas as Iceland, Greenland, Svalbard, and Novaya Zemlya, but probably absent from the Asiatic parts of the Arctic.

\section{Isotoma gorodkovi Martynova, 1970} Fig. 45.

TAXONOMIC REMARKS. The species belongs to an Asiatic-American species group (together with mackenziana and arctica) characterized by the presence of an additional sseta on each tergum, i.e. 77/666 vs the common set for Palaearctic species 66/555, their position on Th.2-3 (Fig. 45) probably being species-specific.

DISTRIBUTION in the East European tundra. Less common than the previous species, found in the Bolshezemel'skaya Tundra and on Dolgii Isl., but not west of them $(11,18,19$, $20,24,27)$.

GENERAL DISTRIBUTION. Additionally to the Bolshezemel'skaya Tundra, found all over the Asiatic coast of the Arctic Ocean (Taimyr, Yamal, Wrangel, Chukotka). A few existing records from the southern parts of Asia are problematic.

\section{Isotoma riparia (Nicolet, 1842)}

DISTRIBUTION in the East European tundra. A characteristic species of hygrophyte communities: various bogs, marshes, banks of ponds and lakes $(6,10,11,13,16,17,19$, $20,21,23)$.

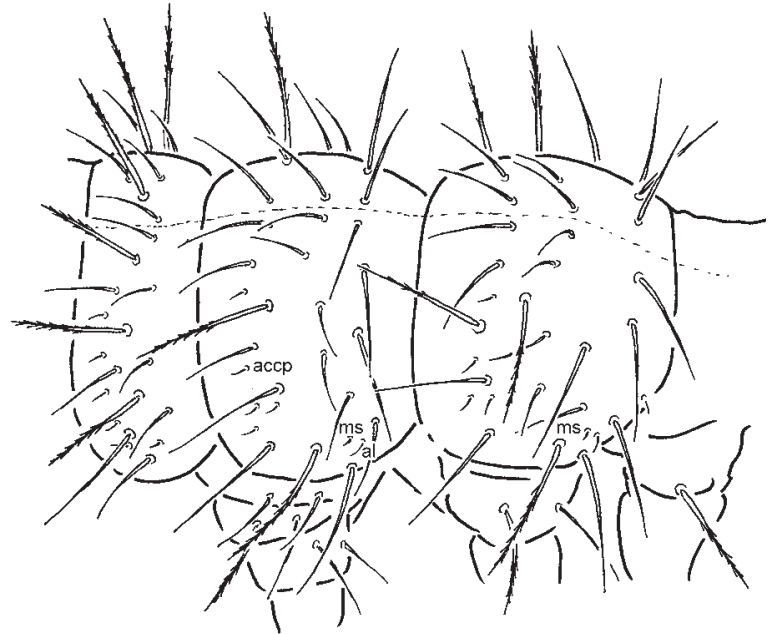

Fig. 45. Isotoma gorodkovi. Chaetotaxy of Th.2-Abd.1, I instar juvenile.

Рис. 45. Isotoma gorodkovi. Хетотаксия Th.2-Abd.1, ювенильный экземпляр 1-ой стадии.

GENERAL DISTRIBUTION. Widespread in Central and Northern Europe, including the European part of Russia, scattered records from the northern Urals, northern and southern Siberia. Records from other Holarctic areas probably need verification.

Isotoma viridis Bourlet, 1839

DISTRIBUTION in the East European tundra. The most common and abundant species of the genus, present in the region in a variety of habitats $\left(1,2,3,5,6,9^{8}, 10,11,12,13\right.$, $15,17,18,19,20,21,22,23,24,25,26,27,28)$.

GENERAL DISTRIBUTION. Recorded all over the Holarctic, but only a few verified Asiatic records are still present. Definitely absent from Greenland, Svalbard, Novaya Zemlya and other Arctic archipelagos.

\section{Isotomiella minor (Schäffer, 1896)}

DISTRIBUTION in the East European tundra. Common, especially so in the southern parts of the region $(5,10,12,13$, $17,18,19,25,26,27,28$ ).

GENERAL DISTRIBUTION. Considered cosmopolitan (excluding truly Arctic sites), but presumably common only in the temperate zones.

Isotomodella alticola (Bagnall, 1949)

DISTRIBUTION in the East European tundra. Not common, only three verified records still present $(13,20,27)$.

GENERAL DISTRIBUTION. Uncertain due to possible confusion with similar blind and slender species with verified records from Greenland, Iceland, Ireland, Great Britain, Norway, northern Sweden, Spitsbergen, Franz Josef Land, and Taimyr Peninsula.

Isotomodella pusilla Martynova, 1967

DISTRIBUTION in the East European tundra. A rare species with a few scattered records for the region $(13,19,20)$.

8 All Linnaniemi's records of the species, i.e. 1, 2, 3, 5, 6, 9, may include several other congeners as he distinguished at least three forms, pallida, violacea (including mirans), and annulata which can hardly be interpreted nowadays 
GENERAL DISTRIBUTION. Probably widely distributed in the Palaearctic with a few remote records in Northern Europe (Norway, Pinega River basin, and the region under consideration) and the Tian-Shan mountains in Central Asia.

Isotomurus chaos Potapov et Babenko, 2011

DISTRIBUTION in the East European tundra. A hygrophilous species typical of the region $(10,20,21,24)$.

GENERAL DISTRIBUTION. Known from several northern regions of the eastern Palaearctic: from the Kanin Peninsula in the west to Chukotka in the east, being more widespread in Siberia.

\section{Isotomurus fucicola (Schött, 1893)}

DISTRIBUTION in the East European tundra. Probably widely distributed in the region, present in almost all adequately investigated areas $(17,18,19,21)$.

GENERAL DISTRIBUTION. Palaearctic, probably widely distributed, but poorly known. Verified records come from Italy [Carapelli et al., 2001], Fennoscandia, including Iceland and Faroe Islands [Fjellberg, 2007a, 2007b], as well as the European [Taskaeva, 2009] and Siberian parts of Russia [Babenko, 2007].

Isotomurus stuxbergi (Tullberg, 1876)

DISTRIBUTION in the East European tundra. Also as common as the previous species $(20,21,23,24)$.

GENERAL DISTRIBUTION. Northern Holarctic.

Pachyotoma crassicauda (Tullberg, 1871)

DISTRIBUTION in the East European tundra. Common in damp sites $(3,10,11,13,15,17,18,20,21)$.

GENERAL DISTRIBUTION. Holarctic, especially widespread in Northern and Central Europe, recorded from the arctic regions of both the Palaearctic (Novaya Zemlya, Taimyr Peninsula and Wrangel Isl., but not found on Svalbard, Iceland and Greenland) and the Nearctic (northern Alaska).

Pachyotoma miserabilis Potapov, sp.n. Figs 46-58.

DIAGNOSIS. A small size species of the genus with 8-11 anterior and 6-11 posterior setae on dens, $2+2$ postlabial setae, and without additional $s$-setae on the third antennal segment.

MATERIAL. Holotype, + , Russia, NE of European part, Nenetsky Autonomous Okrug, Barents Sea, Dolgii Island [69.2236 ${ }^{\circ} \mathrm{N}$ $\left.59.2378^{\circ} \mathrm{E}\right]$, tundra, 11.07 .2004 , O. Makarova leg.

Paratypes: 6 specimens, same sample.

ADDITIONAL MATERIAL. Malozemel'skaya Tundra: Pechora Bay, bank of Kuznetskoye Lake, $68.84^{\circ} \mathrm{N} 53.48^{\circ} \mathrm{E}, 25-26.08 .1994$, A. Babenko leg.

Bolshezemel'skaya Tundra: Pakhancheskaya Guba, $68.48^{\circ} \mathrm{N}$ $57.22^{\circ} \mathrm{E}, 26.07-5.08 .2015$, O. Makarova and M. Bizin leg.; Chernaya River basin, $68.26^{\circ} \mathrm{N} 56.34^{\circ} \mathrm{E}, 4-11.07 .2013$, T. Konakova, G. Nakul leg.; Lakes Padimeiskie, $67.85^{\circ} \mathrm{N} 63.37^{\circ} \mathrm{E}, 18-22.07 .2013$, A. Kudrin leg.; vicinity of Vorkuta, 2007-2015, A. Taskaeva leg.; Vorkuta District, vicinity of Sivaya Maska, Kuz'-Di-Shor Rive (tributary of Usa River), 08.1978, N. Kuznetsova leg.; same area, 07.1985 , V. Kirillova leg.

Vaigach Island: 13.07.1984, V. Bulavintsev leg.; Upper reaches of Talata-Karskaya River, $70.22^{\circ} \mathrm{N} 59.26^{\circ} \mathrm{E}, 22.08 .2010$, N. Zubry and B. Filippov leg.; Vicinity of Varnak, $69.72^{\circ} \mathrm{N} 60.06^{\circ} \mathrm{E}$, 08.07.2015, A. Babenko leg.

Polar and Subpolar Urals: Paga-ty Lake, Pal'nik Lake, $66.37^{\circ} \mathrm{N}$ $62.78^{\circ} \mathrm{E}, 27.06-2.07 .2007$, A. Kolesnikova leg.; Khrebtovy Reserve, 14-21.07.2008, A. Kolesnikova leg.; "Yugyd Va" National Park, Maly Patok River, 7.06.2005, A. Taskaev leg.; "Yugyd Va" National Park, Kozhym River, Maldy-Nyrd Range, 5-13.8.2009, T. Konakova leg.
Northern Urals: Troitsk-Pechorsky District, Pechoro-Ilych Reserve, at confluence of Pechora and Bol'shaya Porozhnyaya rivers, 07.2009, N. Kuznetsova and M. Potapov leg.; Pechoro-Ilych Reserve, Yany-Pupu-N'yer Mount, 02.07.2002, A. Taskaeva leg.; same area, foothills, 30.08.1972, L. Pospelov leg.; Permsky Krai, upper flow of Vizhai River, 7-17.07.2002, $800 \mathrm{~m}$ alt., A. Ermakov leg.; Sverdlovsk District, Masi-Pal-Nel'-Pat-Tur Range, 1922.07.2002, A. Ermakov leg.; Denezkin Kamen' Mount, Rubel' Pass, $1250 \mathrm{~m}$ alt., 07-08.2000, A. Ermakov leg.

Southern Urals, Bashkiria, Bol'shoy Iremel', G. Khanislamova leg.

Western Siberia: vicinity of Salekhard, 27.08.1982, E. Artem'eva leg.; Yamal Peninsula, Mys Kamenny, 1979, V. Nikol'sky and A. Dobrotvorsky leg.; W Yamal Peninsula, Myrtyyakha River, leg. A. Babenko, 22-23.08.1994.

Middle Siberia: Putorana plateau, Dynkenda Mts, surroundings of Yt-Kyuel (=Sobachye) Lake, $70-750 \mathrm{~m}$ alt., $69.11^{\circ} \mathrm{N} 91.70^{\circ} \mathrm{E}$, 07.1997, A. Babenko leg.; vicinity of Turukhansk, mouth of Nizhaya Tunguzka River, $65.80^{\circ} \mathrm{N} 88.11^{\circ} \mathrm{E}, 08.08 .2003$, A. Babenko leg.; Borsky District, left bank of Podkamennaya Tunguska River ( $\sim 30$ $\mathrm{km}$ away from confluence to Yenisey River), $61.6952^{\circ} \mathrm{N} 90.6028^{\circ} \mathrm{E}$, M. Shashkov leg.

DESCRIPTION. Size of fully adult individuals from 0.6 to $0.8 \mathrm{~mm}$. Colour blue, not very dark, appendages paler. Integument with well visible secondary granulation all over the body, no inner reticulation. $8+8$ ocelli, $G$ and $H$ much smaller, $C$ somewhat smaller than others (Fig. 46). PAO narrow elliptical, with weak constriction, partly hidden under integumentary groove; $1.9-2.3$ as long as ocellus diameter, $1.0-1.4$ as long as inner edge of $U_{3}$, and $0.6-0.8$ as Ant.1 width. Maxillary outer lobe with bifurcate palp and 3 sublobal hairs (Fig. 47). Labral formula as 4/5,5,4. Clypeus with about 10 setae, 5 of which arranging in a low transversal row (Fig. 47). Labium with 5 usual papillae $(\grave{A}-\not{A})$, papilla $A$ with a full set of guard setae, guard $e_{7}$ detached and moved backwards. Labium with 3 proximal and 4 basomedian setae. Ventral side of a head with $2+2$ (Fig. 48), rarely $2+3$ postlabial setae. Ant.1 with 2 basal $m s$-setae $(b m s)$, dorsal and ventral, 2 ventral $s$-setae $(s)$, and 13 common setae. Ant.2 with 2 seta-like bms and 1 latero-distal $s$, Ant. 3 with 6 distal $s$ (including 2 lateral) and without $b m s$ (Fig. 51). Outer $s$ setae in antennal organ of Ant.3 longer and much thinner than inner $s$-setae, usually slightly expanded at apex (Fig. 51). Ant.1-3 without additional $s$-setae, $s$-setae on Ant.4 hardly differentiated, subapical organite small.

All setae on body short. Dorsal axial chaetom of Th.2Abd.3 as 4-5,4-5/4(3-5),4(3-5),4-5 (Fig. 52), on next two abdominal segments axial setae arranged more asymmetrically. Thorax without ventral axial setae. Abd.1 with $1-3+1-3$ medial setae on ventral side (Fig. 53, marked). Macrosetae not distinguishable, only a few slightly elongate setae present on last abdominal segment. The largest setae on $\mathrm{Abd} .5$ about 0.15 as long as tergum length. All terga with abundant ssetae, arranged in two groups on each terga: positioned in $p$ row $(a c c p)$ and more anteriorly $(a l+a s)$. Numbers of $s$-setae varies, $s$-formula can be expressed as 5-7+6-7,5-7+4-6/4$6+3,4-6+2-4,6-7+3-4,6-9+4-7,5+2-3$ (for each tergum: posterior $s+$ anterior $s$ ). Tergal $s$-setae curved, cylindrical, hardly differentiated, insignificantly shorter than common setae. Numbers of $m s$-setae as 1,1/1,0,1 (Fig. 52).

Upper subcoxa of Leg 1 without setae. Unguis and unguiculus as common for the genus, without teeth (Fig. 49). The ratio of inner edge of $U_{3}$ to outer edge of $T i_{3}$ as $0.24-0.30$. Unguiculus about half as long as unguis (0.4-0.6). Ti.1-2 sometimes with one additional seta (20-21 at whole on each), tibiotarsi of Leg 3 with several additional setae in proximal part (totally about 25 setae). B-row on Ti.1-2 with 7 setae. Tibiotarsal tenent setae poorly developed, pointed, much 
shorter than $U_{3} . V T$ with 5+5 latero-distal setae, posterior side with 4 setae in distal transversal row and 1-3 setae in more proximal position (Fig. 57). Tenaculum with a seta, $4+4$ teeth, and a pair of small warts on corpus (Fig. 53). Anterior furcal subcoxae divided into two parts, medial with 9-14 setae and lateral with 8-9 setae, posterior furcal subcoxa with 5-7 setae (Fig. 53). Furca of moderate size (Figs 54-56). Anterior side of manubrium smooth, without setae, its posterior side granulated. Medial part of manubrial thickening unispinose, rarely bispinose. Dens with $8-11$ anterior and 611 posterior setae (see also Variability part). Posterior side of dens clearly granulated. Mucro with subapical tooth of varying size and three lamellae, anterior and two posterior ones. Manubrium : dens : mucro ratio $=3.5-5.1: 2.5-3.8: 1$ (see also Variability part).
In several males seen no special sexual dimorphism was observed. Adult males with developed ejaculatory duct are armed with two curved male spurs on tibiotarsi of Leg 3 (Fig $50)$ and several erect $s$-setae on antennae.

VARIABILITY. The specimens of $P$. miserabilis sp.n. from the most eastern parts of the distributional range (Turukhansk, Putorana Plateau, Podkamennaya Tunguska River) are usually characterized by longer furca with slightly more setae: dens with 7-11 posterior setae (vs 6-8 in typical specimens), manubrium : mucro ratio as 3.9-5.1 (vs 3.5-4.1). Mucro in these eastern populations usually has more clear subapical tooth set more distantly from the apical one (Fig. 56). The range of variations in two forms is overlapped and so a reliable conclusion on a state of the 'eastern' form cannot be made so far.

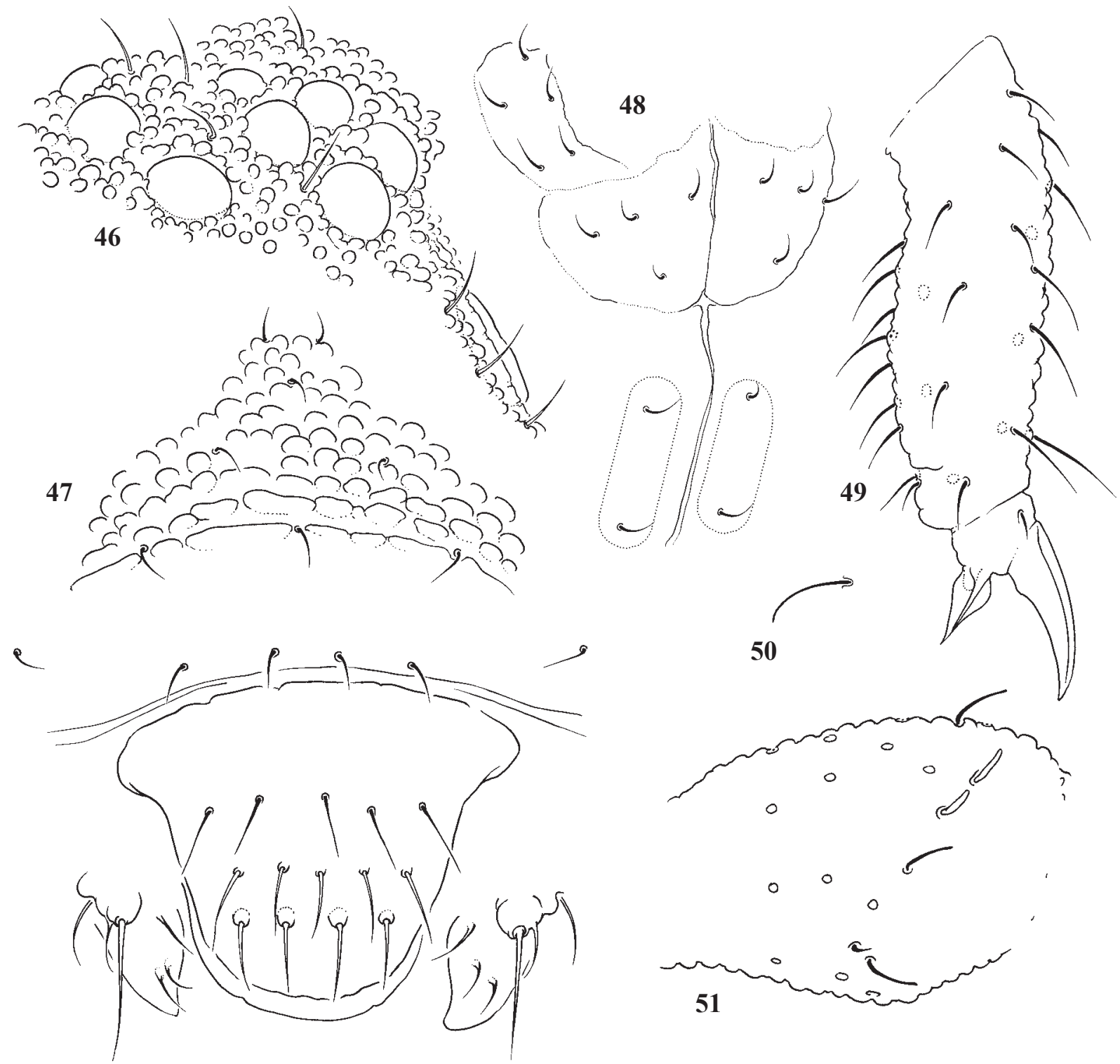

Figs 46-51. Pachyotoma miserabilis sp.n. 46 - PAO and ocelli; 47 - front of head (frontal view); 48 - anterior-medial part of ventral side of head (postlabial setae marked); 49 - tibiotarsus and claw of hind leg in adult female; 50 - male spur on tibiotarsus; 51 - Ant. 3 (lateral view).

Рис. 46-51. Pachyotoma miserabilis sp.n. 46 - постантеннальный орган и глазки; 47 - передняя часть головы (спереди); 48 передне-срединная часть нижней стороны головы ('пост-нижнегубные’ хеты помечены); 49 - голенелапка и коготок половозрелой самки; 50 - самцовая шпора голенелапки; 51 - Ant.3 (сбоку). 
ETYMOLOGY. The species is named because of a very small size of its body.

AFFINITIES. Among Palearctic species, P. miserabilis sp.n. stands in intermediate position between long-furcated species, i.e. P. curva (Gisin, 1949), P. pseudorecta (Haybach, 1972), P. recta (Stach, 1929), P. topsenti (Denis, 1948), and such short-furcated forms as $P$. dabeiensis (Tamura et Zhao,
2000), P. emeiensis Ding, 2007, P. granulata (Stach, 1947), $P$. sajanica (Stebaeva, 1975), and P. stricta (Yosii, 1939). The species of the former group usually have more anterior setae on dens (at least $14-16$ as in $P$. topsenti), while the latter one consists of forms with fewer than 6 such setae. The new species with 8-11 anterior and 6-11 posterior setae on dens shares this number with only $P$. caucasica (Stach, 1947) having 9 anterior

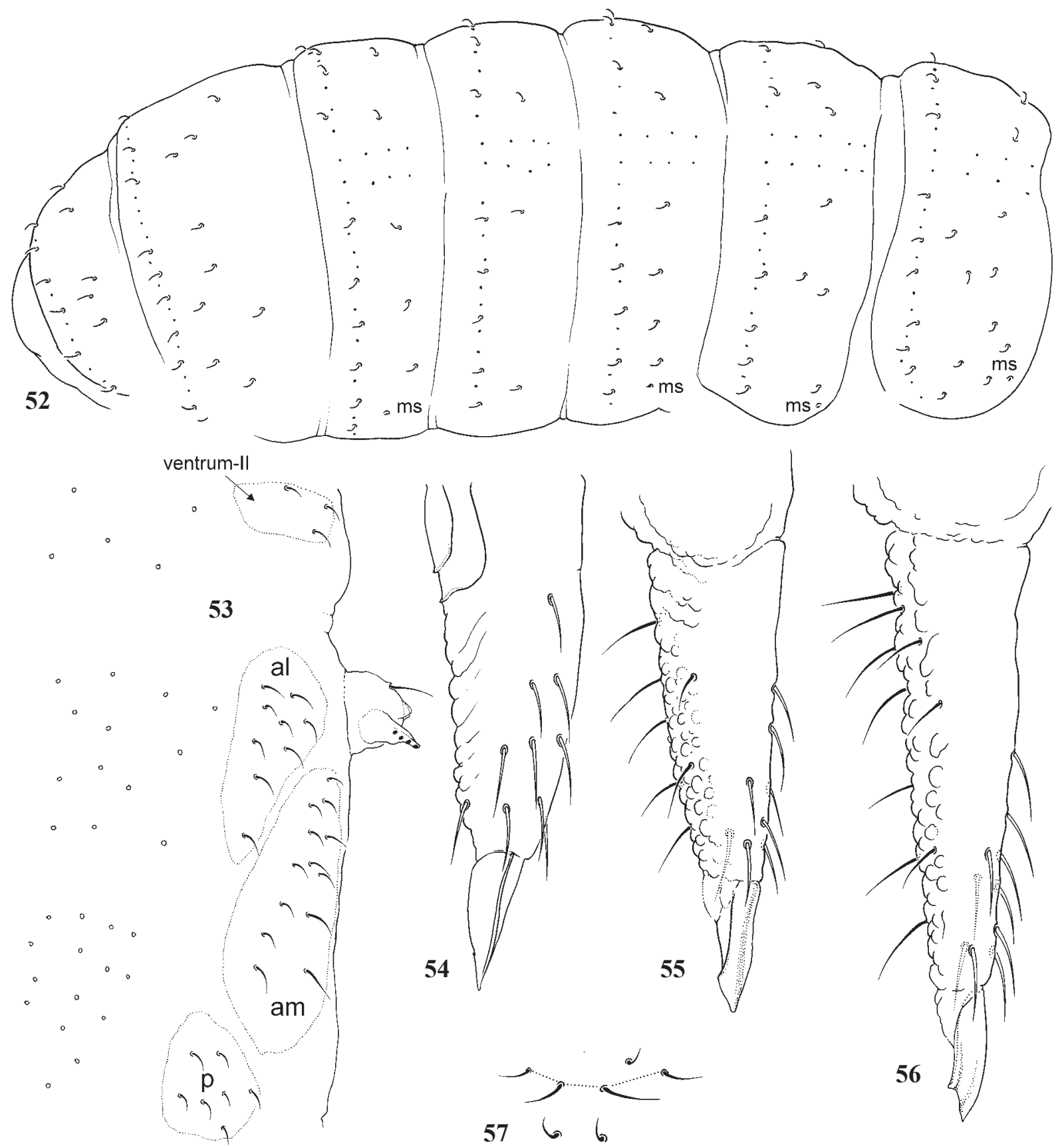

Figs 52-57. Pachyotoma miserabilis sp.n. 52 - one of the variants of $s$-setae, $m s$-setae, $p$-row and axial common setae on body tergites; 53 - ventral chaetotaxy of $A b d .2-4 ; 54-56$ - furca in specimen from Vaigach Island (anterior view) (54), Pakhancheskaya Bay (55), Putorana Plateau (lateral view) (56); 57 - setae of posterior face of ventral tube; al, am, $p$ - setae of anterio-lateral, anterio-medial, and posterior furcal subcoxae; ventrum-II — setae of ventral side of $A b d .2$.

Рис. 52-57. Pachyotoma miserabilis sp.n. 52 - один из вариантов расположения $s$-хет, $m$ s-хет, хет $p$-ряда и осевых хет на тергитах тела; 53 - брюшная хетотаксия $A b d .2-4$; 54-56 - прыгательная вилка у особей с острова Вайгач (вид спереди) (54), из Паханческой Губы (55); плато Путорана (вид сбоку) (56); 57 — хеты задней поверхности брюшной трубки; $a l, a m, p-$ хеты передне-боковых, передне-срединных и задних предтазиков прыгательной вилки; ventrum-II — хеты брюшной стороны Abd.2. 


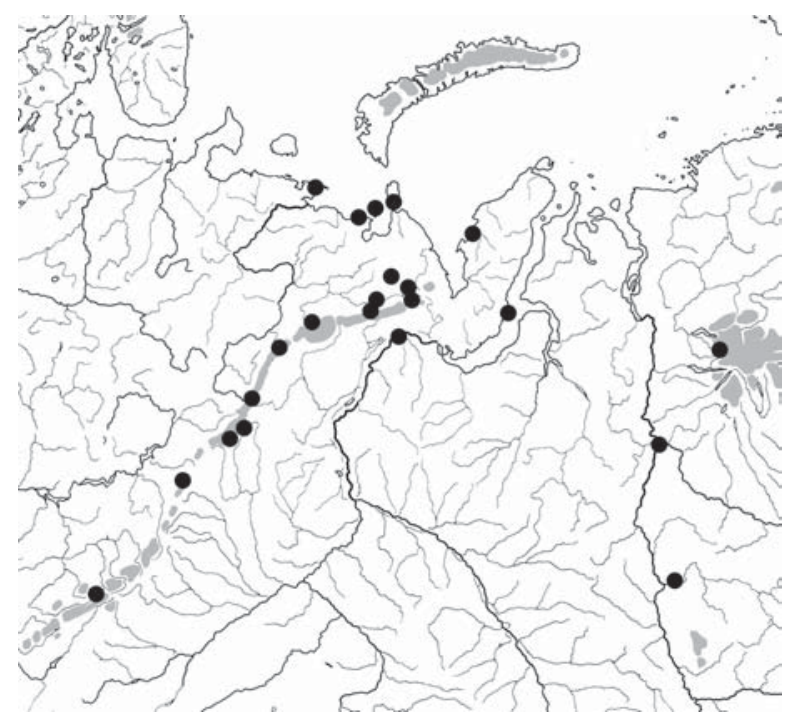

Fig. 58. Pachyotoma miserabilis sp.n. Map of distributional pattern.

Рис. 58. Pachyotoma miserabilis sp.n. Карта распространения.

and $10-11$ posterior setae. According to the original description [Stach, 1947], the Caucasian species differs having subequal ocelli (clearly unequal in P. miserabilis sp.n.), inner tooth on unguis (absent in P. miserabilis sp.n.), and slender mucro (compact in P. miserabilis sp.n.). Apart from this, based on our study of $P$. cancasica material from Armenia, Ant.3 in the latter is armed with many additional $s$-setae (absent in the new species). Among short-furcated Asiatic species, $P$. sajani$c a$ deserves special attention being partly sympatric, although mainly distributed in more south and eastern areas. It clearly differs from $P$. miserabilis sp.n. by more postlabial setae $(4+4)$, fewer teeth on tenaculum $(3+3)$, and the presence of additional $s$-setae on Ant.3.

Two Nearctic species, namely Pachyotoma antigua (Folsom, 1937) (=Proisotoma antigua auct.) and Pachyotoma alpa (Christiansen et Bellinger, 1980), originated from the eastern areas of the U.S.A., have a furca shape which is almost identical to that in P. miserabilis sp.n. The former species can be distinguished from the new species only due to subequal ocelli (more comprehensive comparison is impossible since many essential characters of $P$. antigua are still unknown). $P$. alpa, after a recent detailed redescription [Soto-Adames, Giordano, 2011] clearly differs by the presence of additional s-setae on Ant.3, 3(4)+3(4) postlabial setae, and 4 maxillary sublobal hairs.

DISTRIBUTION in the East European tundra. All over the Bolshezemel'skaya Tundra, contrary to the previous species can be abundant in a wide range of mossy communities from hygrophilous to rather dry $(16,17,18,19,20,22,23$, 24, 26, 27).

GENERAL DISTRIBUTION. Central parts of the Palaearctic, from the eastern corner of Malozemel'skaya Tundra in the west to the Yenisei River basin in the east, penetrating far south along the Urals (Fig. 58). Mainly inhabits different tundra sites both in lowlands and mountains, more rarely in the forested mountain belt. Previously recorded as Pachyotoma sp.nov. [Taskaeva, 2005, 2007; Kolesnikova et al., 2007; 2008, 2010; Goryachkin et al, 2011; Taskaeva et al., 2015], Pachyotoma sp.(n.?) [Babenko, 2002], Pachyotoma sp. [Babenko, 2007, 2012], and as Pachyotoma cilicovi ${ }^{9}$ [Gomina, 2015].

9 nomen nudum
Parisotoma ekmani (Fjellberg, 1977)

DISTRIBUTION in the East European tundra. A typical species of hygrophilous habitats all over the region $(11,13$, $15,17,18,19,20,22,24,25,26,27)$.

GENERAL DISTRIBUTION. Holarctic.

\section{Parisotoma longa (Potapov, 1991)}

TAXONOMIC REMARKS. Apart from the main form, similar colourless specimens characterized by a variable number of distal setae on $V T$ (2-3, but usually 3$)$ and the absence of a seta on lower subcoxa of the fore leg have been found. The same form has also been listed as $P$. sp. aff. longa for Taimyr by Babenko [2013].

DISTRIBUTION in the East European tundra. A few records in the region (19) and (20, as $P$. cf. longa).

GENERAL DISTRIBUTION. Previously recorded only from the Eastern Palaearctic (Taimyr, Tuva, and Chukotka).

\section{Parisotoma notabilis (Schäffer, 1896)}

DISTRIBUTION in the East European tundra. Common and abundant all over the region, often co-occurring with the next species $(10,11,12,13,16,17,18,19,20,21,22,23,24$, $25,26,27,28)$.

GENERAL DISTRIBUTION. Probably cosmopolitan, recorded almost all over the Holarctic, including Greenland, Iceland, Svalbard, and Novaya Zemlya.

\section{Parisotoma reducta (Rusek, 1984)}

DISTRIBUTION in the East European tundra. Also common, but, unlike the previous species, usually more abundant in rather wet sites $(16,17,18,19,20,21,22,23,24,27)$.

GENERAL DISTRIBUTION. Registered all over the Asiatic part of Russia, including its northern and eastern areas; Vaigach Island was the only previous record for $\mathrm{Eu}-$ rope.

Proisotoma minima (Absolon, 1901)

DISTRIBUTION in the East European tundra. Uncommon, only a few records in the region $(15,17)$.

GENERAL DISTRIBUTION. A widespread Holarctic species with a few records from the South Hemisphere.

\section{Pseudanurophorus binoculatus (Kseneman, 1934)}

DISTRIBUTION in the East European tundra. Common, but never especially abundant $(10,11,12,13,18,19,27)$.

GENERAL DISTRIBUTION. Holarctic, including Greenland, Iceland, Jan Mayen, and the Canadian Arctic Archipelago, but probably absent from Svalbard, Franz Josef Land and Severnaya Zemlya.

Pseudisotoma sensibilis (Tullberg, 1876)

DISTRIBUTION in the East European tundra. A polytopic species inhabiting a wide range of different communities: from bogs and marshes to zonal plant associations (16, $17,18,19,20,22,23,24,25)$.

GENERAL DISTRIBUTION. Uncertain due to taxonomic problems, but recorded all over the Holarctic, including both its northern and southern regions.

\section{Pseudisotoma $\mathrm{sp.}$}

TAXONOMIC REMARKS. This undescribed species with an unclear generic position is characterized by $10 / 001$ (ms) and 55/44446 dorsal s-setae set in p-row on Abd.1-4, fused $A b d .5-6$, one clearly clavate seta on each tibiotarsus and long dorsal macrosetae on abdominal tip, densely ciliated all around. All these traits completely fit the diagnosis of 
Pseudisotoma (although $P$. sensibilis has a full number of $m s)$. However, contrary to all other species of the genus, this form possesses a complete set of distal setae on tibiotarsi (11, $11,10)$, bifurcate outer maxillary lobe and four teeth on the mucro which looks like that in P. trichaetosa Martynova. Unfortunately only juvenile specimens are present in the available material.

DISTRIBUTION in the East European tundra. Only two samples from willow bushes on a river bank (17).

GENERAL DISTRIBUTION. Unknown.

\section{Tetracanthella wahlgreni Axelson, 1907}

DISTRIBUTION in the East European tundra. Almost everywhere in various types of communities $(10,11,12,13$, $15,16,17,18,19,20,21,23,24,25,26,27,28)$.

GENERAL DISTRIBUTION. Western Palaearctic (from British Isles in the west to the Taimyr Peninsula in the east).

Vertagopus pseudocinereus Fjellberg, 1975

DISTRIBUTION in the East European tundra. A single verified record (20).

GENERAL DISTRIBUTION. Probably Holarctic, but poorly-known.

Vertagopus westerlundi (Reuter, 1897)

DISTRIBUTION in the East European tundra. Recorded in the southern part of the region (25), another published record (27) is probably erroneous.

GENERAL DISTRIBUTION. Palaearctic.

\section{Tomoceridae}

Tomocerina minuta (Tullberg, 1876)

DISTRIBUTION in the East European tundra. Common, but not especially abundant $(5,10,17,18,19,21,25,26,27,28)$.

GENERAL DISTRIBUTION. An arcto-boreal species with a Holarctic distribution pattern, although Hammer's [1953] record from northern Canada (Yellow Knife) are considered as problematic [Christiansen, 1964].

\section{Tomocerus sibiricus Reuter, 1891}

DISTRIBUTION in the East European tundra. Only Linnaniemi's two old records from the Kanin Peninsula $(2,3)$ and a single recent one from the vicinity of Vorkuta (27).

GENERAL DISTRIBUTION. Central parts of the Palaearctic with the Severnaya Dvina River [Babenko, 2008] as the westernmost region.

\section{Entomobryidae}

Orchesella cincta (Linnaeus, 1758)

DISTRIBUTION in the East European tundra. Not typical of the region, as there is only a single record from the vicinity of Vorkuta (27).

GENERAL DISTRIBUTION. Holarctic.

\section{Orchesella flavescens (Bourlet, 1839)}

DISTRIBUTION in the East European tundra. Scattered records all over the region, uncommon $(3,10,17,21,26,27)$.

GENERAL DISTRIBUTION. Palaearctic, a boreal species very common in forested areas.

Entomobrya marginata (Tullberg, 1871)

DISTRIBUTION in the East European tundra. A few records in the southern belt of the region $(26,27)$.

GENERAL DISTRIBUTION. Considered cosmopolitan, although many old records require confirmation.
Entomobrya nivalis (Linnaeus, 1758)

DISTRIBUTION in the East European tundra. Rather common, but not especially abundant $(10,11,17,18,19,21,26,27)$.

GENERAL DISTRIBUTION. Recorded almost all over the globe, but more than one species can be involved on a world scale.

Lepidocyrtus lignorum (Fabricius, 1793)

DISTRIBUTION in the East European tundra. All over the region, common and abundant $(1,4,6,10,11,12,13,15$, $16,17,18,19,21,26,27)$.

GENERAL DISTRIBUTION. Holarctic, including Iceland and Svalbard; the records from Greenland (as lanuginosus) are still problematic.

Lepidocyrtus violaceus (Geoffroy, 1762)

DISTRIBUTION in the East European tundra. A few verified records $(11,18,21,27)$.

GENERAL DISTRIBUTION. Holarctic, including Greenland, although many records need confirmation.

\section{Neelidae}

Megalothorax minimus Willem, 1900

DISTRIBUTION in the East European tundra. Presumably a species rare in the region, with only a single confirmed record (17), previously might have easily been confused with several congeners.

GENERAL DISTRIBUTION. Considered cosmopolitan, but after the recent revision [Schneider, D'Haese, 2013] only records from Belgium, France, and Chile are verified for sure.

\section{Megalothorax sp.1}

TAXONOMIC REMARKS. A species of the minimusgroup characterized by the absence of a $X$-seta on Ant.4 replaced by a cuticular process, by the presence of $a_{0}$ on the head front, two sublobals on the maxillary outer lobe and flame-shaped inner s-setae in the sensory fields.

DISTRIBUTION in the East European tundra. The most common and abundant species of the genus in the region (10, $12,13,17,18,19,20,21,22$ ?, 23, 24, 25, 27).

GENERAL DISTRIBUTION. This is the most abundant form of the genus registered all along the Arctic coast of the Palaearctic (from the Kola Peninsula to Chukotka, including Northern Island of Novaya Zemlya), recorded also in the mountains of central Yakutia.

\section{Megalothorax sp.2}

TAXONOMIC REMARKS. Another undescribed species of the same group with $X$-seta on Ant.4, one sublobal hair on the maxillary outer lobe, and flame-shaped inner s-setae in sensory fields, a seta $a_{0}$ on the head front absent and replaced by an oval papilla.

DISTRIBUTION in the East-European tundra. Less frequent and abundant than the previous species $(17,18$ ?, 19, 24).

GENERAL DISTRIBUTION. Unknown.

\section{Megalothorax sp.3}

TAXONOMIC REMARKS. Probably an undescribed species of the minimus-group with $X$-seta on Ant.4, one sublobal hair on the maxillary outer lobe and oval inner ssetae in the sensory fields, both seta $a_{0}$ and papilla split into four smaller parts present on the head front.

DISTRIBUTION in the East European tundra. A few specimens found together with all other congeners (17).

GENERAL DISTRIBUTION. Unknown. 


\section{Sminthurididae}

Sminthurides aquaticus (Bourlet, 1842)

DISTRIBUTION in the East European tundra. Scattered records within the region $(3,7,10,20)$.

GENERAL DISTRIBUTION. Holarctic.

Sminthurides malmgreni (Tullberg, 1876)

DISTRIBUTION in the East European tundra. Similar to the previous species $(3,17,18,19,20,21)$.

GENERAL DISTRIBUTION. Holarctic.

Sminthurides parvulus (Krausbauer, 1898)

DISTRIBUTION in the East European tundra. Widespread, but not especially common $(12,17,19,20,21)$.

GENERAL DISTRIBUTION. Palaearctic.

Sminthurides schoetti Axelson, 1903

DISTRIBUTION in the East European tundra. Almost everywhere in damp sites $(17,20,21)$.

GENERAL DISTRIBUTION. Palaearctic.

Sminthurides signatus (Krausbauer, 1898)

DISTRIBUTION in the East European tundra. Only two records on the Kolguev Island $(12,13)$.

GENERAL DISTRIBUTION. Palaearctic.

Sphaeridia furcata Dunger et Bretfeld, 1989

DISTRIBUTION in the East European tundra. A single male collected by pit-trapping on a herbaceous meadow (17).

GENERAL DISTRIBUTION. Poorly known: only three previous records: Germany, Slovenia, and the vicinity of Irkutsk, Siberia [Bretfeld, 1999].

Sphaeridia pumilis (Krausbauer, 1898)

DISTRIBUTION in the East European tundra. Common and widespread, but not abundant $(10,11,12,17,18,19,20$, $22,24,25,26,27)$.

GENERAL DISTRIBUTION. Holarctic, with a few records from the Southern Hemisphere.

Stenacidia violacea (Reuter, 1881)

DISTRIBUTION in the East European tundra. Probably common, but only two records in the eastern parts of the region are available $(20,21)$.

GENERAL DISTRIBUTION. Probably subcosmopolitan.

\section{Katiannidae}

Sminthurinus alpinus Gisin, 1953

DISTRIBUTION in the East European tundra. Common, especially so in rather rich plant communities $(16,17,18,19$, 20, 23, 24).

GENERAL DISTRIBUTION. Palaearctic, but verified records only for its western parts from Europe to Middle Siberia.

Sminthurinus aureus (Lubbock, 1862)

DISTRIBUTION in the East European tundra. Common and widespread, usually found in damp habitats $(13,18,19$, 20, 21, 26, 27).

GENERAL DISTRIBUTION. Palaearctic, including Iceland and Greenland.

Sminthurinus bimaculatus Axelson, 1902

DISTRIBUTION in the East European tundra. Recorded by Babenko et Fjellberg [2006], in fact two specimens collected in 1994 on the Kolguev Island (12) might have been misidentified $S$. aureus which is common in the region $^{10}$.

GENERAL DISTRIBUTION. Uncertain due to confusing with other species of the aureus-group, originally described from forested part of Lapland.

\section{Sminthurinus concolor (Meinert, 1896)}

DISTRIBUTION in the East European tundra. Only two remote records in eastern parts of the region $(20,26)$.

GENERAL DISTRIBUTION. Europe, including Svalbard, Iceland and Greenland.

Sminthurinus igniceps (Reuter, 1881)

DISTRIBUTION in the East European tundra. Only a single published record (27) which is probably erroneous.

GENERAL DISTRIBUTION. According to Bretfeld [1999], there is no recent verified record of the species in the Palaearctic. Moreover, all older European specimens, including the original types, stemmed from various indoor sites such as green- or hot-houses. The only reliable record of the species in a natural habitat is that in Japan [Yosii, 1970], while all of its other reports in open habitats probably deal with varieties of $\mathrm{S}$. niger or undescribed species [Bretfeld, 1999, p. 117].

Sminthurinus niger (Lubbock, 1868)

DISTRIBUTION in the East European tundra. A single record in the southern part of the region (26), yet it probably needs confirmation.

GENERAL DISTRIBUTION. Most of the verified records come from Europe, but the actual distribution still remains uncertain.

\section{Arrhopalitidae}

Arrhopalites cf. caecus (Tullberg, 1871)

DISTRIBUTION in the East European tundra. Only a single record from the region (21).

GENERAL DISTRIBUTION. Palaearctic, widely distributed, but uncommon. There are also a number of records outside the region which probably need confirmation.

Pygmarrhopalites principalis (Stach, 1945)

DISTRIBUTION in the East European tundra. Scattered records all over the region, but never abundant $(11,12,17$, $18,19,20,22,24,25,26,27)$.

GENERAL DISTRIBUTION. Holarctic, including Svalbard, Iceland and Greenland.

\section{Bourletiellidae}

Bourletiella hortensis (Fitch, 1863)

DISTRIBUTION in the East European tundra. Only two records $(20,21)$, in both cases numerous specimens were collected by pit-trapping in rather damp habitats.

GENERAL DISTRIBUTION. Cosmopolitan.

Deuterosminthurus bicinctus flava (Koch, 1840)

DISTRIBUTION in the East European tundra. A single record in a rich herbaceous meadow (17)

GENERAL DISTRIBUTION. Palaearctic.

\footnotetext{
10 The original colouration of specimens cannot be checked because material was cleared, yet morphologically they are identical to S. aureus
} 
Heterosminthurus cf. bilineatus (Bourlet, 1842)

DISTRIBUTION in the East European tundra. A single female collected by pit-trapping in a dry meadow (21).

GENERAL DISTRIBUTION. Palaearctic.

Heterosminthurus stebaevae Bretfeld, 1996

DISTRIBUTION in the East European tundra. Rather common in a variety of damp habitats $(17,18,19,21)$

GENERAL DISTRIBUTION. Widespread in western and Middle Siberia (from the Putorana Plateau to Tuva, the Altai, the Sayan and the Tian-Shan mountains, the westernmost locality previously lying in the middle Urals).

Heterosminthurus claviger Gisin, 1958

DISTRIBUTION in the East European tundra. Only several remote records $(20,26,27)$.

GENERAL DISTRIBUTION. Widespread in the Palaearctic from Europe (including Iceland and Greenland) to the Altai and Tuva.

Heterosminthurus insignis (Reuter, 1876)

DISTRIBUTION in the East European tundra. A single record in the southern part of the region (26).

GENERAL DISTRIBUTION. Palaearctic, but many old records probably need confirmation.

\section{Sminthuridae}

Sminthurus nigromaculatus Tullberg, 1841

DISTRIBUTION in the East European tundra. Common and abundant in a variety of habitats $(17,18,19,20,21)$.

GENERAL DISTRIBUTION. Probably Holarctic, including Iceland and Greenland.

\section{Allacma fusca (Linnaeus, 1758)}

DISTRIBUTION in the East European tundra. There is only Linnaniemi's old record from the southern part of the Kanin Peninsula (1).

GENERAL DISTRIBUTION. Uncertain, most of the verified records come from various part of Europe, including Fennoscandia, but was also recorded in Canada (Quebec).

\section{Dicyrtomidae}

\section{Dicyrtoma christinae Szeptycki, 1981}

DISTRIBUTION in the East European tundra. Rather abundant in a number of water-logged habitats in two areas $(17,21)$

GENERAL DISTRIBUTION. Until now, the species has been recorded only twice: in the original description (Poland, Baltic Sea shore) and, questionably, from the Putorana Plateau [Bretfeld, 2002].

\section{Dicyrtoma fusca (Lubbock, 1873)}

DISTRIBUTION in the East European tundra. Scattered records over the region $(10,18,19,21)$.

GENERAL DISTRIBUTION. Holarctic, with most of the records from Europe, including Iceland and a single one from the Atlantic coast of North America (Nova Scotia). Old records of the species (as Papirius silvaticus) by Tullberg [1876], Schött [1893] and Schäffer [1900] from the Yenisei River basin require confirmation, as well as that of Stebaeva [1976] for the Baraba steppes in western Siberia.

\section{Dicyrtoma ghilarovi Bretfeld, 1996}

DISTRIBUTION in the East European tundra. Only a single area in the central part of the region (17) where species was rather abundant in damp habitats.
GENERAL DISTRIBUTION. Described from a forested area on the Baikal Lake shore, later recorded only in southern Taimyr [Babenko, 2003].

Dicyrtomina minuta (Fabricius, 1783)

DISTRIBUTION in the East European tundra. Uncommon, only two records in a western part of the region $(3,10)$.

GENERAL DISTRIBUTION. Holarctic, but most records stem from Europe, including Iceland, and a few from the Atlantic coast of North America.

Ptenothrix atra (Linnaeus, 1758)

DISTRIBUTION in the East European tundra. Not common, only a single record (17), specimens were collected in a willow bed by pit-trapping.

GENERAL DISTRIBUTION. Palaearctic, recorded from Western Europe [Bretfeld, 1999] to the Yenisei River basin [Stebaeva et al., 1977].

\section{Conclusion}

A total of 192 collembolan species with a few uncertain identifications, altogether belonging to 70 genera and 17 families, are registered in the territory of the East European tundras. This number comprises about $45 \%$ of the arctic fauna of the group, which currently includes more than 420 species [Babenko, Fjellberg, 2006]. The geographic position of the region under consideration close to the border between Europe and Asia suggests a probably mixed composition of its fauna, namely, the presence of a number of European and Siberian elements together with widespread forms. It was even called "Siberia in Europe" by H. Seebohm [1880] who visited the lower reaches of Pechora River in 1875 , paying special attention to its avian fauna. A significant Siberian contribution to the faunal composition of Rhopadocera of the region was highlighted by N.J. Kuznetsov [1925, 1938] and confirmed by recent investigations of A.G. Tatarinov [2016]. The existence of a number of "Siberian" species in the collembolan fauna of the given European region is also well-known from the beginning of the previous century when Linnaniemi [1909] found Tomocerus sibiricus in the tundra of the Kanin Peninsula.

Below we shall try to determine how many such species exist in the regional fauna and what their ratio to true European forms using two adjoining regions, northern Norway and Taimyr, as reference data. As regards the fauna of Collembola, the former territory belongs probably to the best investigated areas of the world, while the latter region's fauna is also known rather adequately. These territories to be compared are obviously not identical, strongly differing both in size (Taimyr is the biggest one, N Norway the smallest) and environmental conditions. Northern Norway is represented by typical highlands with sharply differentiated landscapes and mainly boreal-type of vegetation in valleys. Landscapes in the two other regions are more or less plain with predominance of various hygrophilous communities; furthermore, Taimyr is characterized by significantly more severe climatic conditions. The level of our 
knowledge of regional collembolan faunas differs seriously as well. Northern Norway is covered with sampling sites almost entirely, but even here there is an uneven selection of examine habitats which impose a certain bias [Fjellberg, 1988, p. 16]. Two other territories are surveyed much worse and uneven. Nevertheless, a comparison of these regional faunas can probably be rather productive, even though it must be done with some caution.

The regions compared are characterized by similar level of general diversity of Collembola: 172 species are known for three northernmost administrative units of Norway, i.e. Nordland, Troms, and Finnmark [Fjellberg, 1988, 1998, 2007a], 181 species are reliably registered from the treeless territory of Taimyr [Babenko 2003, 2013], and a slightly higher number (192) are recorded during the present survey. Taking into account differences between these regions and the permanent changes in the group's taxonomy, these estimates of species diversity appear to be surprisingly identical. Diversity at the family level is also fully comparable (Fig. 59). The Tullbergiidae showing the highest diversity in the western regions and the lowest on Taimyr represents the only notable exception.

Comparisons at the specific level are the most interesting and fruitful. Apart from the widespread species common to all three regions, three groups of species can be delimited. The first includes 30 "unique" species found only in the East European tundra, the second one with 39 species characteristic of both European regions (Northern Norway and East European tundra), while the third group (63 species) combines the species inhabit-

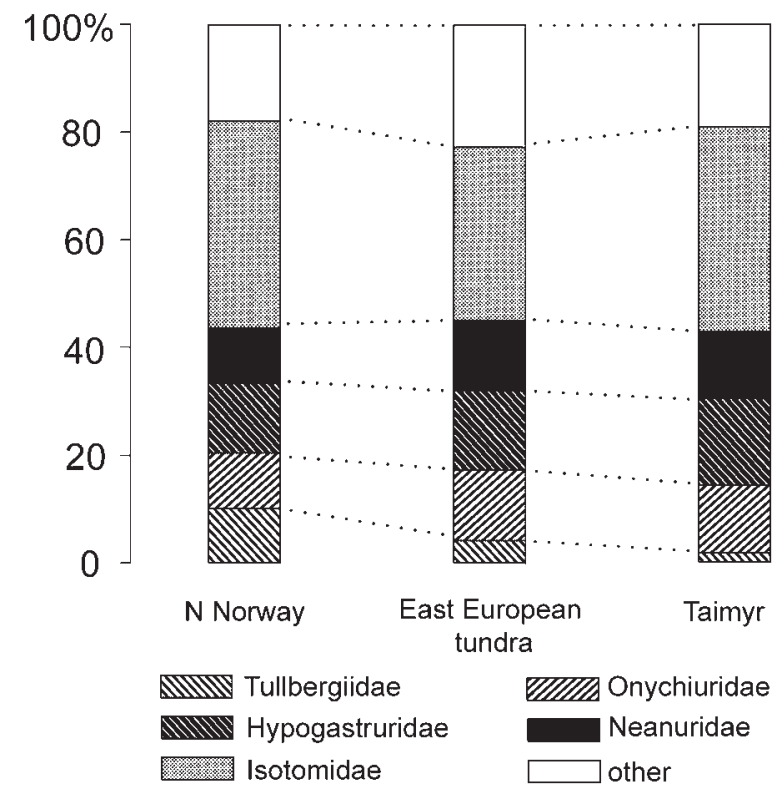

Fig. 59. Relative species richness of families in the collembolan faunas of northern Norway, East European tundra and Taimyr Peninsula.

Рис. 59. Сравнительная представленность семейств в фаунах коллембол северной Норвегии, восточно-европейских тундр и полуострова Таймыр. ing both the East European and Taimyr tundras. Surely all these groups are highly heterogeneous. For instance, the first group of "unique" species mainly consists of different forms whose absence from other region compared could simply be casual or may depend on some ecological factors. In other words, these are rather common species widespread in Europe or in the whole Palaearctic, such as Stenaphorura quadrispina, Schoettella ununguiculata, Hypogastrura litoralis, Pseudachorutes parvulus, Isotoma anglicana, Bourletiella hortensis, Ptenothrix atra, etc. The distribution of six species of the "unique" group, i.e. Tullbergia sp., Hymenaphorura inopinata sp.n., Pseudisotoma sp., Megalothorax sp.2 et sp.3, Pachyotoma miserabilis sp.n., are still uncertain whereas Protaphorura salsa, P. vasilinae, Gisinea subtilia sp.n., Folsomia continentalis, Hemisotoma bibasiosetis, Heterosminthurus stebaevae have previously been known from Siberia, yet from more southern regions than Taimyr. In fact, true "unique" species, i.e. the forms with known distributions coinciding with northeastern Europe, appear to be limited by only two species, Protaphorura stogovi and Anurida komi.

Among 39 species common to northern Norway and the East European tundras, only Megaphorura arctica, Protaphorura macfadyeni, P. pseudovanderdrifti, Uralaphorura schilovi, Xenylla brevicauda, Anurida thalassophila, Desoria tolya, Folsomia dovrensis, and F. thalassophila could possibly be considered as true European species. On the contrary, the main body of the group is comprised of widespread Palaearctic or even Holarctic forms whose absence on Taimyr could probably be related to the severe climatic conditions existing there.

The third group of 63 collembolan species common to the East European and Taimyr tundras is also heterogeneous and includes about a dozen species not found in northern Norway, but widespread in the Palaearctic or even wider, namely Protaphorura boedvarssoni, Supraphorura furcifera, Friesea truncata, Brachystomella parvula, Isotomurus fucicola, I. stuxbergi, Pachyotoma crassicauda, Sminthurides signatus, Stenacidia violacea, Sminthurus alpinus, Heterosminthurus bilineatus, and Sminthurus nigromaculatus. Nevertheless, most species in this group (totally 51 species) do not occur in the mainland Western Europe and can reasonably be considered as a "Siberian" fraction in the collembolan fauna of the East European tundras. Part of these species, i.e. Wankeliella intermedia, Ceratophysella longispina, Hypogastrura concolor, H. tullbergi, Willemia similis, Friesea quinquespinosa, Desoria breviseta sp.n., D. tshernovi, Folsomia binoculata, F. ciliata, $F$. taimyrica, are recorded more westerly only from the arctic islands such as Svalbard or even penetrates into Greenland. In Western Europe, all these species are usually treated as true arctic forms, although some of them can be widely distributed in Siberia. The western range limits of Anurida papillosa, Endonura reticulata, and Folsomia diplophthalma lie in Karelia, those of all other species of the group within the region 
under consideration, i.e. East European tundras. The eastern limits of distribution of these species distribution vary strongly from Eastern Siberia to Canada.

As a whole, "Siberian" forms in the East European tundra regions account for not less than $30 \%$ of the whole collembolan fauna, which significantly surpass a similar ratio of the "European" fraction $(6 \%$, less than $9 \%$ if all unidentified forms are to be considered as local, i.e. European, forms. Thus, the collembolan fauna of the East European tundras might reasonably be treated as a peculiar Siberian enclave in the territory of Europe.

ACKNOWLEDGMENTS. We express our sincere thanks to Louis Deharveng and Cyrille D'Haese (Paris), Valery Bulavintsev, Veronika Kirillova, Natalia Kuznetsova, Olga Makarova, and Mikhail Bizin (Moscow), Vladimir Boeskorov (Yakutsk), Alexander Ermakov (Ekaterinburg), Ivan Bolotov, Boris Filippov (Arkhangelsk), Guzel Khanislamova (Ufa), Alla Kolesnikova, Tatyana Konakova, Alexey Kudrin, Anatoly Taskaev (Syktyvkar), Maxim Shashkov (Puschino) for the loan of valuable material. A vast material for the paper was collected during the Arctic Floating University expedition on board of "Professor Molchanov" Research Ship, organized by The Lomonosov Northern Arctic Federal University in 2015. We would like to thank all organizers and participants of this pleasant and fruitful cruise and Konstantin Zaikov and Boris Filippov, personally. Many thanks should be also given to Elena Lapteva (Syktyvkar) which did a great deal organizing our field work at Chernaya River and Lakes Padymeiskie. We are also much indebted to Sergei Golovatch (Moscow) kindly edited the English of an advance draft, as well as to anonymous reviewers for critical and suggestive remarks.

The paper has been financially supported through the joint project of the United Nations Development Programme (UNDP) and the Ministry of Natural Resources and Environment of the Russian Federation "Challenges of diversity conservation in politics and developmental programmes of the energy sector of the Russian economy" (2014-2016), by programme "Animal kingdom of the European North-East of Russia under economic exploitation and environmental changes" ( $\left.{ }^{1} 115012860088\right)$, grants of the Russian Foundation for Basic Research (14-04-01114a, and 16-44-110989 -à), several scientific programmes of the Russian Academy of Sciences including one of Ural Branch of Academy ( ${ }^{1} 15-15-4$ 46). For the second author, the paper has been supported through the Ministry of Education and Science of the Russian Federation (project No 6.632.2014/K).

\section{References}

Arbea J.I., Jordana R. 1994. Cuatro nuevas especies de la familia Onychiuridae de la Península Ibérica (Collembola, Poduromorpha) // Publicaciones de Biología de la Universidad de Navarra, Serie Zoológica. Vol.24. P.39-59.

Babenko A.B. 1997. The taxonomy and distribution of the genus Anurida (Collembola, Neanuridae) in the northern Palaearctic / European Journal of Entomology. Vol.94. P.511-536.

Babenko A.B. 2002. Springtails of Western Putorana Plateau (Middle Siberia): Fauna and Altitude Differentiation of Assemblages // Entomological Review. Vol.82. No.7. P.901-919 [original Russian text: Zoologicheskii Zhurnal. Vol.81. No.7. P.779-796].

Babenko A.B. 2003. Landscape chorology of Collembola in the Taimyr Peninsula: biotopic distribution of species // Entomological Review. Vol.83. No.8. P.1003-1021 [original Russian text: Zoologicheskii Zhurnal. Vol.82. No.8. P.937-952].
Babenko A.B. 2007. Collembolan fauna of the Turukhansk Territory // Russian Entomological Journal. Vol.16. No.4. P.361-383.

Babenko A.B. 2008. Springtails (Hexapoda, Collembola) in karst landscapes of the Pinega State Reserve // Entomological Review. Vol.88. No.2. P.150-163 DOI: 10.1134/ S0013873808020036 [original Russian text: Zoologicheskii Zhurnal. Vol.87. No.3. P.292-305].

Babenko A.B. 2012. Springtails (Hexapoda, Collembola) of tundra landscapes of the Kola Peninsula // Entomological Review. Vol.92. No.5. P.497-515 DOI: $10.1134 / \mathrm{S} 0013873812050028$ [original Russian text: Zoologicheskii Zhurnal. Vol.91. No.4. P.411-427].

Babenko A.B. 2013. "Collembola of the Western Taimyr": forty years later // Entomological Review. Vol.93. No.6. P.737-754 DOI: $10.1134 / \mathrm{S} 0013873813060079$ [original Russian text: Zoologicheskii Zhurnal. Vol.92. No.4. P.428-444].

Babenko A.B., Potapov M.B., Stebaeva S.K., Chernova N.M. 1994. Opredelitel kollembol fauny Rossii i sopredel'nykh stran. Semeistvo Hypogastruridae [Collembola of Russia and adjacent countries: Family Hypogastruridae]. Moscow: Nauka. 336 pp. [in Russian].

Babenko A., Fjellberg A. 2006. Collembola septentrionale. A catalogue of springtails of the Arctic regions. Moscow: KMK Scientific Press Ltd. 190 pp.

Babenko A.B., Kaprus' I.J. 2014. Species of the genus Protaphorura (Collembola: Onychiuridae) described on material of Yu.I. Chernov from Western Taimyr // Entomological Review. Vol.94. No.4. P.581-601. DOI: 10.1134/S0013873814040113 [original Russian text: Zoologicheskii Zhurnal. Vol.93. No.1. P.147166].

Bombusova E.P., Kuznetsova N.A. 1981. [Microarthropods of forested tundra soils in the vicinity of Sivaya Maska] // Problemy pochvennoi zoologii [Abstracts of the VII All-Union conference on Soil Zoology]. Kiev: Radynske Zakarpattya. P.34-35 [in Russian].

Bretfeld G. 1999. Synopses on Palaearctic Collembola. Symphypleona // Abhandlungen und Berichte des Naturkundemuseums, Görlitz. Bd.71. Hf.1. 318 S.

Bretfeld G. 2002. Fourth report on Symphypleona from Russia with descriptions of four new species (Insecta, Collembola) // Abhandlungen und Berichte des Naturkundemuseums, Görlitz. Bd.74. Hf.2. S.159-191.

Carapelli A., Frati F., Fanciulli P.P., Dallai R., 2001. Taxonomic revision of 14 south-western European species of Isotomurus (Collembola, Isotomidae), with description of four new species and the designation of the neotype for I. palustris // Zoologica Scripta. Vol.30. No.2. P.115-143.

Christiansen K.A. 1964. A revision of the Nearctic members of the genus Tomocerus (Collembola Entomobryidae) // Revue d'Écologie et de Biologie du Sol. T.1. Livr.4. P.639-678.

Coulson S.J., Fjellberg A., Gwiazdowicz D.J., Lebedeva N.V., Melekhina E.N., Solhøy T., Erséus Ch., Maraldo K., Miko L., Schatz H., Schmelz R.M., Søli G., Stur E. 2013. Introduction of invertebrates into the High Arctic via imported soils: the case of Barentsburg in the Svalbard // Biological Invasions. Vol.15. P.1-5. DOI 10.1007/s10530-012-0277-y.

Coulson S.J., Fjellberg A., Melekhina E.N., Taskaeva A.A., Lebedeva N.V., Belkina O.A., Seniczak S., Seniczak A., Gwiazdowicz D.J. 2015. Microarthropod communities of industrially disturbed or imported soils in the High Arctic; the abandoned coal mining town of Pyramiden, Svalbard // Biodiversity Conservation. Vol.24. P.1671-1690. DOI 10.1007/s10531-015-0885-9.

D'Haese C.A. 2003. Homology and morphology in Poduromorpha (Hexapoda, Collembola) // European Journal of Entomology. Vol.101. P.385-407.

Dunger W., Schlitt B. 2011. Synopses on Palaearctic Collembola. Tullbergiidae // Soil Organisms. Vol.83. No.1. 168 pp.

Fjellberg A. 1979. Revision of the European species of the Isotoma olivacea-group (Collembola, Isotomidae) // Entomologica Scandinavica. Vol.10. P.91-108.

Fjellberg A. 1988. The Collembola fauna of Troms and Finnmark, North Norway // Fauna Norvegica. Vol.35B. P.5-20. 
Fjellberg A. 1998. The Collembola of Fennoscandia and Denmark. Part I: Poduromorpha // Fauna Entomologica Scandinavica. Vol.35. $183 \mathrm{pp}$.

Fjellberg A. 2007a. The Collembola of Fennoscandia and Denmark. Part II: Entomobryomorpha and Symphypleona // Fauna Entomologica Scandinavica. Vol.42. 264 pp.

Fjellberg A. 2007b. Icelandic Collembola - revised checklist and general comments // Insects Systematics and Evolution. Suppl.64. P.45-60.

Fjellberg A. 2015. Collembola (springtails, collembolans) // J. Böcher et al. (eds.). The Greenland Entomofauna. An Identification Manual for Insects, Spiders and their Allies. Chapter 6. LeidenBoston: Brill. P.48-82.

Gomina A.E. 2015. [Collembola assemblages in main types of hardwoods in the upper reaches of Pechora river] // Trudy Pechoro-Ilychskogo zapovednika [Proceedings of the PechoroIlychskii Nature Reserve]. No.17. P.58-61 [in Russian].

Goryachkin S.V., Gilichinskii G.A., Gubin S.V., Lapteva E.M., Lupachev A.V., Fedorov-Davydov D.G., Zazovskaya E.P., Mazhitova G.G., Mergelov N.S., Vinogradoca Yu.A., Melechina E.N., Taskaeva A.A. 2011. [A state of the Arctic and Subarctic soils with regard to the period of International Polar Year] // Polyarnaya kriosfera i vody sushi. Moscow: Paulsen. P.193-218 [in Russian]

Greenslade P. 1994. Collembola // Zoological catalogue of Australia. Vol.22: Protura, Collembola, Diplura (Houston W.W.K., ed.). Melbourne: CSIRO Australia. P.19-138.

Gulgenova A., Potapov M. 2013. New 'oligopseudocellar' Protaphorura species (Collembola: Onychiuridae) from East Palaearctic // Soil Organisms. Vol.85. No.3. P.203-213.

Hammer M. 1953. Investigations on the microfauna of Northern Canada. II. Collembola // Acta Arctica. Vol.6. 108 pp.

Hogg I.D., Hebert P.D.N. 2004. Biological identification of springtails (Hexapoda: Collembola) from the Canadian Arctic, using mitochondrial DNA barcodes // Canadian Journal of Zoology. Vol.82. P.749-754.

Kaprus' I., Pomorski R.J. 2008. Review of the Palaearctic Protaphorura Absolon, 1901 species of octopunctata group (Collembola: Onychiuridae) // Annales Zoologici (Warszawa). Vol.58. No.4. P.667-688.

Kolesnikova A.A., Melechina E.N., Taskaeva A.A. 2007. [Soil invertebrates] // Bioraznoobrazie ekosistem Polarnogo Urala. M.V. Getsen (ed.). Syktyvkar. P.182-202 [in Russian].

Kolesnikova A.A., Melechina E.N., Taskaeva A.A. 2008. [Soil invertebrates in Subarctic tundras of the European part of Russia] // Sever: arkticheskii vector sotsialno-ekologicheskikh issledovanii. Syktyvkar. P.295-315 [in Russian].

Kolesnikova A.A., Taskaeva A.A., Melechina E.N. 2010. [Soil invertebrates] // Biologicheskoe raznoobrazie osobo okhranyaemykh prirodnykh territorii Respubliki Komi. No.7. Prirodnye kompleksy zakaznika "Khrebtovyi”. Syktyvkar. P.67-77 [in Russian].

Kozlovskaya L.S. 1955. [To the characteristic of soil fauna of the Bolshezemel'skaya Tundra] // Doklady Akademii nauk SSSR. Vol.104. No.3. P.485-486 [in Russian].

Kozlovskaya L.S. 1957. [Comparative characteristics of soil fauna in transpolar part of Usa River basin] // Trudy Instituta lesa, Akademia nauk SSSR. Vol.36. P.165-177 [in Russian].

Kuznetsov N.J. 1925. Some new eastern and American elements in the fauna of Lepidoptera of the Polar Europe // Comptes rendus de l'Académie des sciences de l'URSS. Seria A. P. $119-122$.

Kuznetsov N.J. 1938. [Arctic fauna of Eurasia and its origin; a study based mainly on Lepidoptera] // Travaux de l'Institut Zoologique de l'Académie des sciences de l'URSS. T. 5. Livr. 1. P. 1-85 [in Russian].

Linnaniemi (Axelson) W.M. 1909. Zur Kenntnis der Collembolenfauna der Halbinsel Kanin und benachbarter Gebiete // Acta Societatis pro Fauna et Flora fennica. Vol.33. No.2. P.1-17.

Linnaniemi W.M. 1919. Resultats scientifiques de 1'Expedition des freres Kuznecov a L'Oural Arctique en 1909, sous la derection de H. Backlund // Memoires de Academie des Sciences de Russie. VIII serie. Vol.28. No.13. P.1-15.
MacLean S.F., Behan V., Fjellberg A. 1978. Soil Acari and Collembola from Chaun Bay, Northern Chukotka // Arctic and Alpine Research. Vol.10. No.3. P.559-568.

Mari Mutt J.A., Bellinger P.F. 1990. A Catalog of the Neotropical Collembola including Nearctic areas of Mexico. Flora \& Fauna Handbook. No.5. Gainesville, Florida: Sandhill Grane Press. $237 \mathrm{pp}$.

Massoud Z. 1965. Description d'un nouveau genre de Collembole cavernocole d'Europe // Annales de Spéléologie. T.20. Fasc.3. P.431-435.

Pomorski R.J. 1993. Two new species of Protaphorura Absolon, 1901 from north Karelia (Russia), with notes on the position of altered pseudocelli (psx) in the armatus-group // Genus (Wroclaw). Vol.4. No.2. P.121-128.

Pomorski R.J. 2001. Revue of the genus Hymenaphorura Bagnall, 1948 with descriptions of eleven new species from North America and Siberia // Insect Systematics \& Evolution. Vol.32. P.439-474

Pomorski R.J., Skarżyński D. 1995. Springtails (Collembola) collected in Chupa Inlet region (N Karelia, Russia) // Acta Universitatis Wratislaviensis. No.1744. P.47-57.

Porco D., Skarżyński D., Thibaud D., Hebert P.D., Deharveng L. 2014. Barcoding the Collembola of Churchill: a molecular taxonomic reassessment of species diversity in a sub-Arctic area // Molecular Ecology Resources. Vol.14. No.2. P.249-261. DOI: 10.1111/ 1755-0998.12172.

Potapov M.B. 2001. Synopses on Palaearctic Collembola. III. Isotomidae // Abhandlungen und Berichte des Naturkundemuseums, Görlitz. Bd.73. Hf.2. 603 S.

Potapov M.B., Stebaeva S.K. 1990. [Species of the genus Anurophorus Nicolet, 1842 (Collembola: Isotomidae, Anurophorinae) in the fauna of the USSR] // Novye i maloizvestnye vidy fauny Sibiri [New or little known species in the fauna of Siberia]. Novosibirsk: Nauka. P.15-49 [in Russian].

Potapov M.B., Babenko A.B. 2000. Species of the genus Folsomia (Collembola: Isotomidae) of the northern Asia // European Journal of Entomology. Vol.97. P.57-74.

Potapov M.B., Dunger W.G. 2000. A redescription of Folsomia diplophthalma (Axelson, 1902) and two new species of the genus Folsomia from continental Asia (Insecta: Collembola) // Abhandlungen und Berichte des Naturkundemuseums, Görlitz. Bd.72. Hf.1. S.59-72.

Rusek J. 1980. Notes on three Folsomia-species (Collembola) // Věstník československé Společnosti zoologické. Vol.44. P.139145.

Schäffer C. 1900. Die arctischen und subarctischen Collembola // Fauna Arctica. Vol.1. P.147-216.

Schneider C., D'Haese C.A. 2013. A morphological and molecular insights on Megalothorax: the largest Neelipleona genus revisited (Collembola) // Invertebrate Systematics. Vol.27. P.317364. DOI: $10.1071 /$ IS13002.

Schött H. 1893. Zur Systematik und Verbreitung palearctischen Collembola // Kongliga Svenska Vetenskaps-Akademiens Handlingar. Bd.25. No.11. S.1-100.

Seebohm H. 1880. Siberia in Europe: a visit to the valley of the Petchora, in North-East Russia; with description of the natural history, migration of birds, etc. London: John Murray. 311 pp.

Smolis A., Deharveng L., Kaprus' I.J. 2011. Studies on the nonEuropean Endonura Cassagnau, 1979 (Collembola, Neanuridae, Neanurinae) // Zootaxa. Vol.3004. P.45-56.

Soto-Adames F.N., Giordano R. 2011. New species of springtails in the Proisotoma genus complex from Vermont and New York, USA with descriptive notes on Ballistura alpa Christiansen \& Bellinger 1980 (Hexapoda, Collembola, Isotomidae) // ZooKeys. Vol.147. P.19-37. DOI: 10.3897/zookeys.147.2093.

Stach J. 1947. The Apterygotan fauna of Poland in relation to the world fauna of this group of insects. Family: Isotomidae. Polska Akademia Umiejętności, Kraków. 488 pp.

Stebaeva S.K. 1976. [The state of knowledge of Siberia's springtail fauna (Collembola) in a zonal aspect] // Trudy Biologicheskogo Instituta Sibirskogo otdeleniya AN SSR. Vol.18. P.85-133 [in Russian]. 
Stebaeva S.K., Sukhova T.I., Shcherbakov D.Yu. 1977. [Different life-forms of springtails (Collembola) in relation to a gradient of temperatures] // Zoologicheskii Zhurnal. Vol.56. No.7. P.10211029 [in Russian].

Taskaeva A.A. 2005. [Collembolan fauna of KOMI Republic] // Vestnik Instituta Biologii. No.10. P.16-21 [in Russian].

Taskaeva A.A. 2007. [Soil invertebrates] // V.I. Ponomarev (ed.) Bassein reki Malyi Patok: dikay priroda. Syktyvkar: Parus. P.111-128 [in Russian].

Taskaeva A.A. 2009. Springtail (Collembola) assemblages in floodlands of the taiga zone of the Republic of Komi // Entomologica Review. Vol.89. No.8. P.965-974 DOI: 10.1134/ S0013873809080119 [original Russian text: Zoologicheskii Zhurnal. Vol.88. No.9. P.1055-1063].

Taskaeva A.A., Nakul G.L. 2010. [Collembolan assemblage in seagull colonies of Kolokolkovaya Guba]// Aktualnye problemy biologii i ecologii [Abstracts of the XVII All-Russian conference of young scientists]. Syktyvkar. P.120-122 [in Russian].

Taskaeva A.A., Nakul G.L. 2011. [Fauna and populations of Collembola at the Velt River mouth, Malozemel'skaya Tundra] // Problemy pochvennoi zoologii [Abstracts of the XVI All-Russian conference on Soil Zoology] (4-7 October 2011, Rostovon-Don). Moscow: KMK Scientific Press Ltd. P.127-128 [in Russian].
Taskaeva A.A., Kudrin A.A., Konakova T.N., Kolesnikova A.A. 2015. Diversity of soil invertebrates in ecosystems near the Padimeyskie lakes in the Bolshezemelskaya tundra region of Russia// Euroasian Entomological Journal. Vol.14. No.5. P.480488 [in Russian].

Tatarinov A.G. 2016. [Geography of Rhopalocera of European North-East of Russia]. Moscow: KMK Scientific Press Ltd. 256 pp. [in Russian].

Thibaud J.-M., Schulz H.-J., Gama da M.M.A. 2004. Synopsis on Palaearctic Collembola. IV. Hypogastruridae // Abhandlungen und Berichte des Naturkundemuseums, Görlitz. Bd.75. Hf.2. $287 \mathrm{~S}$.

Tullberg T. 1876. Collembola borealia. Nordiska Collembola beskrifna af Tycho Tullberg // Öfversigt af Kongliga Vetenskaps Akademiens Förhandlingar. Bd.33. No.5. P.23-42.

Yosii R. 1970. On some Collembola of Japan and adjacent countries. II // Contributions from the Biological Laboratory, Kyoto University. Vol.23. No.1. P.1-32.

Zubrii N.A., Kolosova Yu.C., Taskaeva A.A., Melechina E.N. 2011. [Activity of soil and herpetobiont invertebrates during winters] // Bogolitcin K.G., Bolotov I.N. (eds.). Funktsionirovanie subarkticheskoi gidrotermal'noi ekosistemy v zimnii period. Ekaterinburg: UrO RAN. P.183-193 [in Russian]. 